\title{
IMPACT OF FINANCIAL CRISIS ON HEDGING EFFECTIVENESS OF FUTURES CONTRACTS: EVIDENCE FROM THE NATIONAL STOCK EXCHANGE OF INDIA
}

Kapil Gupta, Mandeep Kaur

\section{Abstract}

The present study examines the impact of the 2008 financial crisis on the hedging effectiveness of three index futures contracts traded on the National Stock Exchange of India for near, next and far month contracts over the sample period of January 2000 - June 2014. The hedge ratios were calculated using eight methods; Naive hedging, Ederington's Model, Autoregressive Integrated Moving Average, Vector Autoregressive, Vector Error Correction Methodology, Generalized Autoregressive Conditional Heteroskedasticity, Exponential Generalized Autoregressive Conditional Heteroscedasticity and Threshold Generalized Autoregressive Conditional Heteroskedasticity. The study finds an improvement in hedging effectiveness during the post-crisis period, which implies that during the high-volatility period hedging effectiveness also improves. It was also found that near month futures contracts are a more effective tool for hedging as compared to next and far month contracts, which imply that liquidity is a more important determinant of hedging effectiveness than hedge horizons. The study also finds that a time-invariant hedge ratio is more efficient than time-variant hedging. Therefore, knowledge of sophisticated econometrical tools does not help to improve hedge effectiveness.

Keywords: Hedge ratio, hedge horizon, financial crisis, heteroscedasticity, conditional volatility

JEL: C13, C22, C32, D81, D82, G14, N25 and 016

\section{INTRODUCTION}

Risk is omnipresent in all financial transactions and has become the center stage of every economic activity. The need to manage price risk against unwanted fluctuations in asset value by hedgers and risk-averse investors has led to the emergence of derivatives like futures, options, swaps ,etc. (Bose, 2006) Specifically, hedging involves transferring price risk from entities less willing to take risk to those more willing or able to do so. Therefore, besides hedgers, speculators also very actively trade in the futures market.

Ederington (1979) suggests that a hedge is said to be effective if it reduces portfolio variance to a minimum level and is highly affected by the behavior of basis1, the liquidity of futures contracts, the time-to-

1 Basis in the literature means difference between futures price and cash price. maturity of futures contracts, the risk aversion of investors, hedge horizons and price trends in the market (eg. See Figlewski, 1984). For instance; Chang et al., (2010), observed that hedge effectiveness is found to be higher in a bull market than in a bear market, which may be attributed to the fact that low volatility appears in uptick markets and vice-versa.

Kapil Gupta, PhD

Assistant Professor

Punjab institute of Management (PIM), India

\section{Mandeep Kaur}

Research Scholar

Punjab institute of Management (PIM), India

E-mail:kaur_mandeep13@ymail.com 
King and Wadhwani (1990); Majid and Kassim (2009); Karim et al. (2011) and Sugimoto et al. (2014) also observe that a financial crisis in one country always devastates the financial health of other major economies of the world in terms of its spillover effect. The recent financial crisis of 2008 originated in the United States and spread over Europe and Asia, thus weakening their economic and financial strength (Joshi, 2012). A major impact has been observed in the financial health of these nations in the form of significant changes in the structure of price trends in their financial markets. The crisis drove down equity levels across the globe and major stock markets of the world exhibited the persistence of the volatility during the crisis and post-crisis period (Mazumder and Ahmad, 2010; Al-Rjoub and Azzam, 2012; Ali and Afzal, 2012 and Singhania and Anchalia, 2013).

It has also been observed that the global financial crisis of 2008 significantly impacted the volatility of the Indian stock market (Ali and Afzal, 2012; Joshi, 2012 and Dufrénot and Keddad, 2014). Moreover, futures trading is not only popular in developed markets of the world, but is equally popular in emerging markets like India, which is evident from the fact that Indian equity futures consistently rank amongst the top five markets of the world for the last decade2. However, to the best of our knowledge, in the Indian context only a few attempts have been made to examine hedge effectiveness (Bhaduri and Durai, 2007; Rao and Thakur, 2008; Gupta and Singh, 2009 and Pradhan, 2011) and these studies have primarily focused on examining a superior methodology for determining an optimal hedge ratio. Therefore, the present study is an attempt to shore this literature gap by examining the impact of the 2008 financial crisis on the hedging effectiveness of futures contracts, and also to study the relationship between hedging effectiveness, price trends and the time-to-maturity of equity futures contracts in India.

Further discussion in the study has been organized into four sections: Section 2 presents a detailed literature review of hedging; Section 3 discusses the database and research methodology employed for estimating optimal hedge ratios and examining hedging effectiveness; Section 4 analyzes the results, and Section 5 concludes the study.

\section{REVIEW OF LITERATURE}

A strand of literature (see Table 2) observes that the success of hedging depends upon the strong and

2 Please see Monthly Reports published by the World Federation of Exchanges at www.world-exchanges.org stable relationship between cash and the futures market that allows the hedger to hedge the price risk contained in his / her portfolio. However, Figlewski (1984); Castelino (1992) and Dimson and Mussavian (1998) also observe that the existence of various market anomalies (like noise trading by investors, interest rate changes, transaction costs, seasonal variations, demand and supply conditions, informational inefficiency, thin trading, etc.) disturbs the relationship between cash and futures markets, which leads to variation in basis, thereby affecting the efficiency of hedges. Hence, the presence of an efficient futures market (exhibited by an efficient price discovery mechanism, information assimilation efficiency and the existence of a strong arbitrage base) is a pre-requisite for efficient hedging.

Early investigations in hedging literature has led to the development of three different hedging theories based upon the varied objectives of investors, which includes conventional (traditional or naive) hedging theory, Working's hedging theory and Portfolio hedging theory. The conventional / naive hedging theory assumes that the price movement in cash and futures markets is perfectly correlated as both markets are exposed to a common information set and the investor is a risk averter. Hence, it suggests that the optimal hedge ratio is to have an equal number of futures contracts as spot exposures, but in the inverse direction, i.e. a long position in futures and a short position in cash, and vice versa. Thus, naive-hedging theory allows hedgers to transfer the risk of price changes in the portfolio to speculators more willing to bear such risks (Floros and Vougas, 2004). However, this theory fails to cater to basis risk, i.e. the movement / change in spread between spot and futures prices. Moreover, in practice, it is unlikely that a perfect correlation exists between cash and futures prices. Therefore, in order to hedge both price risk and basis risk, Working (1953) unveiled a new approach to hedging where the hedger acts as a speculator and not as a risk avoider, thus contradicting the naive hedging theory. Working argued that the objective of hedging is not to minimize risk, but to maximize profits by speculating on basis. Thus, this theory suggests that a long hedger will hedge portfolio risk if the basis is expected to rise, whereas a short hedger will hedge if the basis is expected to fall (Gupta and Singh, 2009).

While Working's theory proved to be an improvement over the naive-hedging theory, it suffers from an unrealistic assumption that hedgers can maximize their wealth at any level of risk. Therefore, Johnson (1960) and Stein (1961) came out with a portfolio approach to hedging that was further extended and quantified by Ederington (1979). As per this approach, 
the hedger's objective is neither to minimize portfolio risk (variance) nor to maximize profits at any level of risk, but to optimize the risk-return trade-off in the portfolio. An important contribution of the portfolio approach is the concept of the Minimum-Variance Hedge Ratio (MVHR), i.e., the hedge ratio that minimizes the risk of the hedged position (Ederington, 1979). Conventional hedging theory and Working's hedging theory help in estimating a constant hedge ratio only, whereas portfolio hedging theory allows for estimating constant as well as time-varying optimal hedge ratios.

Among the three hedging theories discussed above, portfolio hedging theory became most popular because it allows for the estimation of both constant as well as time-varying hedge ratios, unlike naive hedging theory and Working's hedging theory. As observed by Johnson (1960) and Stein (1961), the hedger always prefers a portfolio that optimizes risk and return. Hence, a hedger may choose the best hedge ratio from a wide range of hedge ratios lying on an efficient frontier, depending upon his / her risk preference. Though both naive and Ederinton's hedge ratios assume the investor to be a risk averter, unlike naive-hedge ratio, Ederington's hedge ratio is slope coefficients, which is computed as the ratio of the covariance of futures and cash market returns to the variance of future returns.

The traditional, Working (1953) and Ederington (1979) hedging theories have assumed the hedge ratios to be constant. However, it is a well-established fact that a financial time series observes time varying patterns, and that volatility clustering is their innate feature (Gupta and Singh, 2009). Hence, voluminous literature has found that time-varying hedge ratios are superior to constant hedge ratios (Myers, 1991; Park and Switzer, 1995; Aggarwal and Demaskey, 1997; Moschini and Myers, 2002; Harris and Shen, 2003; Pattarin and Ferretti, 2004; Kofman and McGlenchy, 2005; Floros and Vougas, 2006; Bhaduri and Durai, 2007; Lee and Yoder, 2007 and Yang and Lai, 2009). Furthermore, Yang and Allen (2004) confirmed that a time-varying hedge ratio performs better during out of sample hedging. However, Lien (2005) observed that the OLS hedge ratio outperforms the time-varying hedge ratio, which is confirmed by the findings of Bhargava and Malhotra (2007), who found that OLS performs better during the short-run. Furthermore, Lien and Luo (1994) commented that both constant as well as time-varying hedge ratios are equally efficient when the trader is extremely risk averse.

Ederington (1979) further suggested that futures hedging for longer periods performs much better than for shorter periods, which is also consistent with the findings of Figlewski (1984) who observed that a one day hedge is comparatively less effective than a one week hedge due to the presence of higher basis risk. Furthermore, Chen et al. (2002) also found that as the investment horizon increases, higher hedging effectiveness is observed, which may be due to the fact that market over-reactions are found in shorter horizons, but that rationality prevails in longer horizons. Chen et al. (2004) also found that hedge ratios and their efficiency have a positive relationship with the hedging horizon, which implies that if a hedging horizon is long, then the naive-hedge ratio will be close to the minimum variance hedge ratio. Juhl et al., (2012) also found that when cash and future prices are cointegrated, a longer hedge horizon yields an optimal hedge ratio close to the naive hedge ratio. Moreover, In and Kim (2006) mentions that hedging effectiveness does not only depend upon hedging horizon, but that the risk aversion of the hedger also affects hedging effectiveness, which implies that investors with low risk aversion have short-run hedge ratios and vice versa. Furthermore, Neuberger (1991) found that the rollover of futures contract adds to hedging effectiveness.

Moreover, Figlewski (1984) found that basis risk (arising from unexpected dividends on cash portfolios, transaction costs, hedge duration and time to expiration) is an important determinant of an efficient hedge ratio. A strand of literature (Table 2) has also observed that basis risk is positively associated with the time-to-expiry of futures contracts. Hence, for contract expiry, the hedger will be left with price risk only, implying that naive hedge ratio may be an efficient hedge ratio when a contract is approaching its expiry date, which is consistent with the findings of Ederington (1979). Moreover, Monoyios and Sarno (2002) found that the speed of adjustment of basis towards its equilibrium value is an increasing function of the size of the deviations from equilibrium.

Figlewski (1984) and Stoll and Whaley (1987) suggests that cash and futures markets do not tend to move together. Therefore, an estimation of the optimal hedge ratio becomes essential for risk management. Advancements in the literature of econometrics have led to the development of numerous methodologies for estimating an optimal hedge ratio, which can be either constant hedge ratios (such as Ordinary Least Square (OLS, VAR, VECM, etc.), or time varying hedge ratios (such as GARCH, EGARCH, TARCH, BGARCH, etc.). Floros and Vougas (2004) compared hedge ratios estimated through four models i.e. OLS, ECM, VECM and M-GARCH, and their findings indicate that the M-GARCH model provides lower hedge ratios compared to other models, and captures time 
variation, thereby improving hedging performance at a lower cost. On the other hand, Gupta and Singh (2009) found that the hedge ratio estimated through VAR and VECM reduced the portfolio variance to the largest extent as compared to other methodologies, as the cash and futures market observes long-run comovement. However, Hatemi and Roca (2006) suggested that the use of the Kalman Filter approach for estimating the time-varying hedge ratio has been found to be more efficient. They also suggested that the time path of the estimated hedge ratio can be analyzed to determine volatility in the hedge ratio, which has implications in terms of the cost of rebalancing a hedged portfolio. Thus, hedgers can evaluate the suitability of the hedging instrument to be used. A strand of literature (See Table 2) examining the effectiveness of optimal hedge ratios has found that time-varying hedge ratios are superior to constant hedge ratios.

However, Gupta and Singh (2009) also suggested that hedging through liquid futures contracts by estimating the long-run hedge ratio involves low hedging cost and provides flexibility to hedgers with respect to time-to-expiry. Similarly, Bhaduri and Durai (2007) compared the optimal hedge ratios estimated from four models, i.e. OLS, VAR, VECM and DVEC$\mathrm{GARCH}$ and their results indicate that the time varying hedge ratio derived from DVEC-GARCH provides better hedging effectiveness in terms of mean returns and average variance reduction. However, hedge ratios estimated through OLS out-perform the hedge ratios estimated by other methods at short time horizons in terms of average variance reduction. Rao and Thakur (2007) also examined the efficiency for the Indian Futures market and Indian options markets by comparing the JSE (Johnson, 1960; Stein, 1961 and Ederington, 1979) and HKM (Herbst, Kare and Marshall, 1993) methodology for futures and fBM (Fractional Brownian Motion) and BSM (Black-Scholes Model, 1973) methodology for options. Their findings indicate that the HKM methodology in the case of futures and the fBM methodology in the case of options yield Optimal Hedge ratios in the Indian Futures and Options markets, respectively.

The estimation of an optimal hedge ratio in all models assumes that the distribution of returns on the hedged portfolio is normal, which means that the mean and variance alone are sufficient to determine the optimal hedge ratio. However, there exists indisputable evidence to suggest that the return distributions of speculative assets depart from normality (Brooks et al., 2012). Therefore, Brooks et al., (2012) observed that ignorance of higher moments leads to sub-optimal hedge ratios and suggests a new methodology considering the impact of higher moments on the determination of optimal hedge ratios.

Moreover, asymmetrical behavior of hedging effectiveness, Khatib and Hatemi-J (2011) observed that optimal hedge ratios also exhibit asymmetrical behavior. Their findings imply that an optimal hedge ratio is different when an investor expects a price increase at maturity and is different when investors expect a price decrease at maturity. The reason for this asymmetrical behavior can be attributed to the fact that investors respond more to negative shocks than to positive ones, which leads to the asymmetric behavior of stock returns (Longin and Solnic, 2001). Furthermore, Alizad and Nomikos (2004) also observed that hedge ratios are significantly different across different states of the market, and found that more efficient hedge ratios may be obtained if the hedge ratios are allowed to be dependent upon the state of the market.

On the basis of the discussion above, it can be observed that the debate related to estimation of an optimal hedge ratio has not yet been settled. Most studies covering the issues of hedging effectiveness have been undertaken only in developed economies (see Table 2). However, to the best of our knowledge, only a few studies have been undertaken in emerging economies such as India. The studies that have addressed the issue of hedging effectiveness on stock index futures market in India include Bhaduri and Durai (2007); Rao and Thakur (2008); Gupta and Singh (2009) and Pradhan (2011). The nevertheless, the scope of these studies was limited to finding a superior methodology to estimate an optimal hedge ratio in the equity futures market. Moreover, as discussed in Section 1 , the global financial crisis of 2008 enhanced the volatility of Indian equity markets. Therefore, the present study also attempts to examine the relationship between hedge effectiveness, price trends and the timeto-maturity of equity futures contracts in India during the pre- and post-global financial crisis period.

\section{DATABASE AND RESEARCH METHODOLOGY}

In India, the derivatives market was introduced in the year 2000 on the recommendation of the L.C. Gupta Committee to meet the need for providing a risk management program to both investors and industry. The first financial derivative, Sensex futures, was launched on the Bombay Stock Exchange of India Ltd. (BSE), which commenced its trading on June 9, 2000, followed by the National Stock exchange of India Ltd. (NSE), which launched S\&PCNXNIFTY futures for near, next and far month contracts on June 12, 2000.

Since the inception of the derivatives market, the equity futures market has shown phenomenal growth 
both in terms of volume of contracts and number of products. During 2013-14, the total number of index futures traded on NSE was 105,270,529, and stock futures $170,414,1863$. The range of products, which started with index futures contracts, now includes index futures and options, stock futures and options, interest rate futures, currency futures and bond futures. Despite an initial slow pick up, the number of options contracts traded has observed significant growth after 2007-08, whereas, the number of futures contracts traded has observed a declining trend since then. The business growth of the futures and options segment at the NSE is presented below.

The scope of the present study, however, is restricted to equity futures contracts. The sample size of the study comprises three indices: S\&PCNXNIFTY, CNXIT and BANKNIFTY which were selected on the basis of their consistent trading history and high liquidity. The data was collected for near month, next month and far month contracts for all three indices comprising the study sample from the official website of the National Stock Exchange of India (NSE) at www.nseindia.com.
The period of the study is from the inception date of the respective indices up to June 30, 2014 as presented below:

Hedging theory requires that the trader take simultaneous but opposite-in-sign trading positions in two markets with the magnitude of prediction of one market (cash / futures market) through the other (futures / cash market), which is known as the hedge ratio. Since estimation of the hedge ratio is a statistical process involving regressing cash market returns on futures returns, prior to undertaking any statistical procedures it is important to examine the time series properties of the data under investigation. The very first step in any econometric investigation of a time series is to examine whether that time series contains unit roots. If it does, then it should be transformed for further examination; otherwise the statistical results would be spurious. Therefore, the stationarity of the three indices understudy has been tested by using the Augmented Dickey Fuller (ADF) test, and it has been observed that the prices (both futures prices and cash prices) are non-stationary, whereas, the natural

Graph 1: Business growth of the Futures and Options Segment (Number of Contracts Traded)

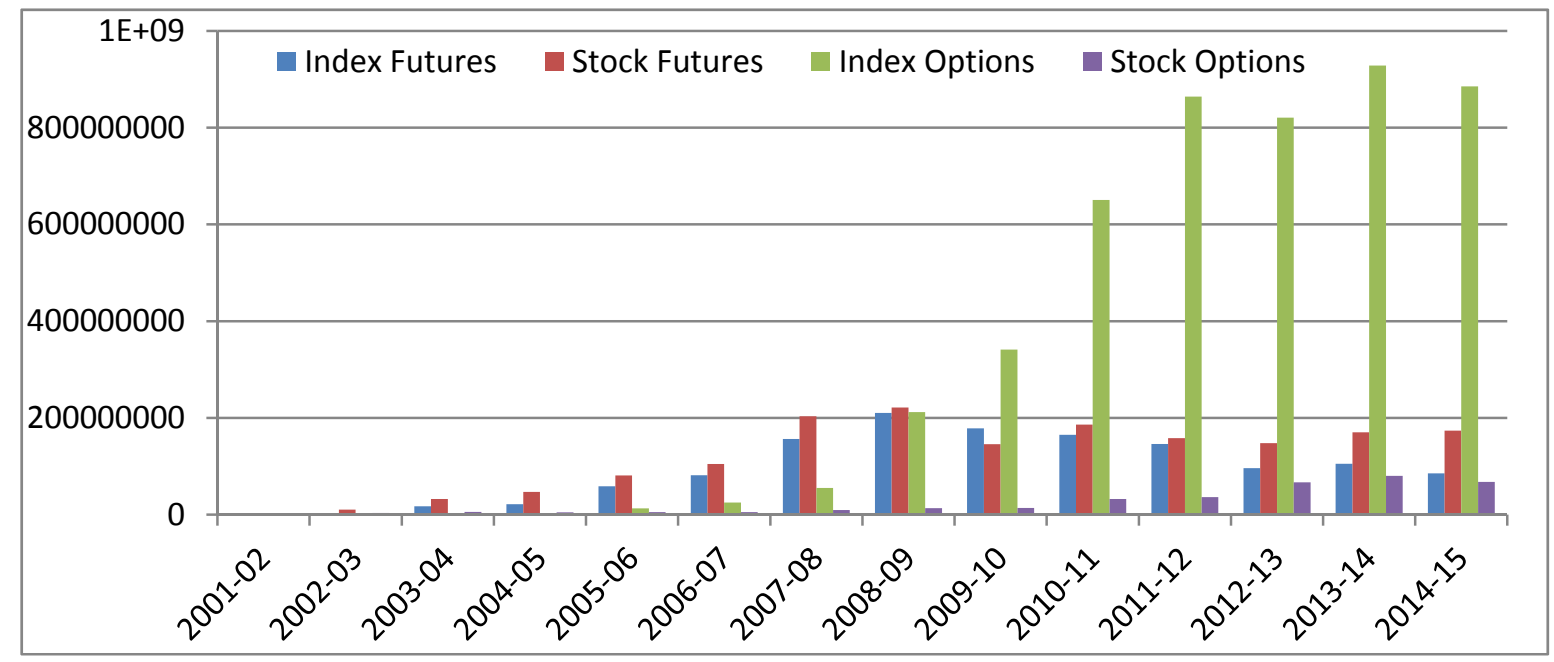

Source: www.nseindia.com

Table 1: Sample Size and Sample Period of Study

\begin{tabular}{|c|c|c|c|c|}
\hline \multirow{2}{*}{ Symbol } & \multirow{2}{*}{ Period of study } & \multicolumn{2}{|c|}{$\begin{array}{c}\text { Number of Observations } \\
\text { (For Near, Next and Far Month contracts) }\end{array}$} & \multirow{2}{*}{ Total } \\
\hline & & Pre-crisis & Post-crisis & \\
\hline S\&PCNXNIFTY & June 12, 2000 - June 30, 2014 & 1898 & 1573 & 3471 \\
\hline CNXIT & August 29, 2003 - June 30, 2014 & 1092 & 1611 & 2703 \\
\hline BANKNIFTY & June 13, 2005 - June 30, 2014 & 638 & 1612 & 2250 \\
\hline
\end{tabular}


$\log$ of the first difference of prices (i.e. $\left.\ln \left(\mathrm{p}_{\mathrm{t}} / \mathrm{p}_{\mathrm{t}-1}\right)\right)$ is stationary4. Thus, the returns of futures contracts and the cash market are considered for estimating hedge ratios.

Moreover, since both cash and futures markets are linked through an arbitrage process (Stoll and Whaley, 1987), and the price of the futures contract determined through a cost-of-carry model in longrun is not expected to be different from spot price plus risk premium to hold positions in the cash market. Therefore, appreciating the stationary and stable long-run relationship between the two markets, five econometric procedures have been undertaken that address various economic as well as statistical issues involved in estimating an optimal hedge ratio. Among these would be an efficient hedge ratio, which can help hedgers minimize portfolio variance.

Furthermore, Ederington (1979) suggests a minimum variance hedge ratio, which presumes a strong and stable long run relationship between the two markets, and where hedging effectiveness will depend upon the coefficient of $R^{2}$. Equation (4.1) explains the procedure suggested by Ederington (1979), which works efficiently when futures market returns are an unbiased predictor of cash market returns. In equation (4.1), $\mathrm{R}_{\mathrm{s}, \mathrm{t}}$ is cash market returns, $\mathrm{R}_{\mathrm{f}, \mathrm{t}}$ is futures market returns, $\alpha_{o}$ is the intercept term and $\varepsilon_{t}$ is the error term. Therefore, as per the cost-of-carry model, futures returns are assumed to be an unbiased predictor of prospective cash market return, hence the intercept and error term should not be significantly different from 0 , and consequently $\mathrm{R}^{2}$ will improve.

$$
\mathrm{R}_{\mathrm{s}, \mathrm{t}}=\alpha_{0}+\beta_{1} \mathrm{R}_{\mathrm{f}, \mathrm{t}}+\varepsilon_{\mathrm{t}}
$$

Equation (4.1) may be economically justifiable, but until the statistical properties of the estimation procedure are satisfied, the estimated value of $\beta_{1}$ won't be reliable. In addition to containing unit roots, another feature of the financial time series is that these are autocorrelated, which implies that successive returns of one speculative asset are significantly predictable. Significantly autocorrelated cash and futures market returns suggest that successive stock and / or futures returns are not random, but rather due to mean reversion, volatility clustering, information asymmetry or an inefficient microstructure that are a function of the previous information set(s) (Fama, 1970 and 1991 and Dimson and Mussavian, 1998). Therefore, if stock returns are autocorrelated, then avoidance of it may

4 The estimated results are not reported in the paper, but, are available on demand. bias the estimated hedge ratio. Hence, equation (4.1) modified to equation (4.2) (to include the autoregressive terms 5 of cash market returns), may provide better results, and hence an improved $\mathrm{R}^{2}$, which otherwise could have been biased on account of significant serial correlation. In equation (4.2), $\mathrm{R}_{\mathrm{s}, \mathrm{t}}$ is cash market returns, $R_{f, t}$ is (are) futures market returns, $R_{s, t-i}$ is autoregressive term(s) whose order varies between $i$ to $p$ determined as per Schwartz Information Criteria (SIC), $\alpha_{o}$ is the intercept term and $\varepsilon_{t}$ is the error term.

$$
\mathrm{R}_{\mathrm{s}, \mathrm{t}}=\alpha_{0}+\sum_{i=1}^{p} \alpha_{i} R_{s, t-i}+\beta_{1} R_{f, t}+\varepsilon_{t}
$$

Literature on financial econometrics has further observed that stock returns observe volatility clustering, which implies that an information set continues to affect stock return the volatility of the few periods ahead. In other words, volatility clustering implies that large price changes will be followed by large price changes, and small price changes will be followed by small price changes. In equations (4.1 and 4.2), if the variance of the error term is constant6, the hedge ratio estimated through the Ordinary Least Square (OLS) method will be valid; however, a vast amount of academic literature (Engle, 1982; Bollerslev, 1987; Myers, 1991; Park and Switzer, 1995; Floros and Vougas, 2004 and Pattarin and Ferretti, 2004) has suggested that stock returns are heteroscedastic in nature. Therefore, the Autoregressive Conditional Heteroscedasticity model (ARCH) (Engle, 1982) generalized by Bollerslev (1986) called GARCH (p, q) applies, in which conditional variance depends not only upon the squared residuals of the mean equation but also on its own past values. The GARCH (p, q) model is given by equation (4.3)

$$
\mathrm{h}_{\mathrm{t}}=\omega+\sum_{i=1}^{p} \alpha_{i} \varepsilon_{t-i}^{2}+\sum_{j=1}^{p} \beta_{j} h_{t-j}+v_{t}
$$

5 Order of autoregression has been determined on the basis of Schwartz criteria. The Schwartz criterion uses a function of the residual sum of squares together with a penalty for large number of parameters. Specifically, the Schwartz information criterion minimizes the expression: $T^{*} \log (R S S)+K^{*}(\log T)$, where $T$ is the number of observations, RSS is the sum of the squared residuals and $K$ is the number of regressors. Lagged terms provide an explanation of the short-run deviations from the long-run equilibrium for the two test equations.

6 The Langrage Multiplier Test, whose null hypothesis states that the variance of error term is homoscedastic. Therefore, rejection of the null hypothesis will ask the researcher to apply an appropriate model from the GARCH family. 
Where, $h_{t}$ is the conditional volatility, $\alpha_{i}$ is the coefficient of the ARCH term with order $i$ to $p$ and $\beta_{j}$ is the coefficient of the GARCH term with order $j$ to $q$. The conditional volatility as defined in equation (4.3) is determined by three effects: the intercept term $(\omega)$, the ARCH term $\left(\alpha_{\mathrm{i}} \varepsilon_{\mathrm{t}-\mathrm{i}}^{2}\right)$ and the forecasted volatility from the previous period called the GARCH component $\left(\beta_{\mathrm{j}} \mathrm{h}_{\mathrm{t}-\mathrm{j}}\right)$. Parameters $\omega$ and $\alpha$ should be higher than 0 , and $\beta_{j}$ should be positive in order to ensure conditional variance $\left(h_{t}\right)$ to be non-negative. In addition, it is necessary that $\alpha_{i}+\beta_{j} \leq 1$, which secures covariance stationarity of conditional variance. Therefore, if the variance of the error term in equation (4.2) is not constant, equation (4.3) would be attached to equation (4.2), meaning the estimation of the hedge ratio $\left(\beta_{1}\right)$ would be subject to the nature of the index return's volatility.

Furthermore, Nelson (1991), by taking into account the asymmetric relationship between conditional volatility and conditional mean, proposes an Exponential GARCH (EGARCH) model based upon the logarithmic expression of conditional volatility in cash and futures market returns. If the stock returns are asymmetric and the interaction between old and new information observes leverage effects, the EGARCH model (i.e. equation (4.4)) may help to estimate an improved hedge ratio as compared to that estimated through the GARCH process in equation (4.3)

$$
\mathrm{h}_{\mathrm{t}}=\gamma_{1}+\gamma_{2}\left|\frac{\varepsilon_{\mathrm{t}-1}^{2}}{\mathrm{~h}_{\mathrm{t}-1}}\right|+\gamma_{3} \frac{\varepsilon_{\mathrm{t}-1}^{2}}{\mathrm{~h}_{\mathrm{t}-1}}+\gamma_{4} \mathrm{~h}_{\mathrm{t}-1}
$$

Equation (4.4) reports the leverage relationship between the old and new information, but in speculative markets, besides the leverage effect, it has been observed that traders react heterogeneously to positive and negative news. For instance, Karpoff (1987), in a survey on the relationship between information arrival (trading volume as a proxy for information arrival) and the behavior of stock market volatility, has reported that volatility in the declining market was always higher than in the rising market. Therefore, it would be more appropriate (if conditional volatility behaves differently to positive and negative news) to segregate the impact of both positive and negative news, which can be done by specifying the variance equation in the TARCH (Threshold Autoregressive Conditional Heteroscedasticity) framework and then estimating the optimal hedge ratio in the mean equation.

Equation (4.5) lays down the variance equation of the TARCH model, where equation (4.4) is modified to include $\varepsilon_{\mathrm{t}-\mathrm{i}}^{2} \xi_{\mathrm{t}-\mathrm{i}}$, which is a dummy for negative news having value 1 if there is negative news and 0 otherwise. Therefore, an appropriate GARCH methodology would be able to capture the stylized behavior of the conditional volatility of cash market returns, and hence the estimated hedge ratio will be statistically robust.

$$
\mathrm{h}_{\mathrm{t}}=\omega+\sum_{i=1}^{p} \alpha_{i} \varepsilon_{t-i}^{2}+\sum_{i=1}^{p} \alpha_{k} \varepsilon_{t-1}^{2} \xi_{t-i}+\sum_{j=1}^{p} \beta_{j} h_{t-j}+v_{t}
$$

where
(a) $\xi_{\mathrm{t}-\mathrm{i}}=1$, if $\varepsilon_{\mathrm{t}-\mathrm{i}}<0$
(b) $\xi_{\mathrm{t}-\mathrm{i}}=0$, if $\varepsilon_{\mathrm{t}-\mathrm{i}}>0$

The estimation of the hedge ratio through OLS, GARCH or EGARCH processes may provide better estimates of the hedge ratio, but the optimality of the hedge ratio will still be doubtful because both markets observe a significant lead-lag relationship in terms of volatility spillover and information dissemination. Therefore, estimating an optimal hedge ratio by regressing only the cash market returns on the lagged returns of both futures and cash market may be biased because the converse is also true, as the volatility spillover is bidirectional and continuous. Therefore, in the present case, either the Vector Autoregression Model (VAR) (when both markets observe causal relationships) or the Vector Error Correction Methodology (VECM) (when both markets are cointegrated) may provide efficient speculative forecasts, and hence a robust hedge ratio may be estimated.

The VAR model simultaneously regresses the lagged returns of both variables, whereas VECM, in addition to lagged returns, also considers the error correction term (if both series are cointegrated). Hence both methodologies estimate the optimal hedge ratio by considering the theoretical relationship between the two markets (i.e. lead-lag in the short-run and cointegration in the long-run), which confirms the volatility spillover between the two markets through the arbitrage process. Equations (4.6) and (4.7) specify the estimation process of the VAR methodology, while equations (4.8) and (4.9) stimulate the estimation procedure of VECM. The hedge ratio, on the basis of VAR and VECM, will be computed as $\sigma_{\mathrm{s}, \mathrm{f}} / \sigma_{f}^{2}$, where

$$
\begin{aligned}
& \sigma_{\mathrm{s}, \mathrm{f}}=\operatorname{cov}\left(\varepsilon_{\mathrm{ft}}, \varepsilon_{\mathrm{st}}\right) \text { and } \sigma_{f}^{2}=\operatorname{var}\left(\varepsilon_{\mathrm{ft}}\right) . \\
& \mathrm{R}_{\mathrm{s}, \mathrm{t}}=\sum_{i=1}^{M} \alpha_{i} R_{s, t-i}+\sum_{j=1}^{N} \beta_{j} R_{f, t-j}+\varepsilon_{s t} \\
& \mathrm{R}_{\mathrm{f}, \mathrm{t}}=\sum_{k=1}^{O} \alpha_{k} R_{s, t-k}+\sum_{l=1}^{P} \beta_{1} R_{s, t-1}+\varepsilon_{f t}
\end{aligned}
$$




$$
\begin{aligned}
& \mathrm{R}_{\mathrm{f}, \mathrm{t}}=\alpha_{0 f}+\sum_{i=1}^{p} \alpha_{i f}\left(F_{t-i}-S_{t-i}\right)+\sum_{j=1}^{q} \beta_{f} R_{f, t-j}+\sum_{k=1}^{m} \beta_{f} R_{s, t-k}+\varepsilon_{f t} \\
& \mathrm{R}_{\mathrm{s}, \mathrm{t}}=\alpha_{0 s}+\sum_{i=1}^{p} \alpha_{i s}\left(F_{t-i}-S_{t-i}\right)+\sum_{l=1}^{n} \beta_{s} R_{s, t-l}+\sum_{h=1}^{o} \beta_{s} R_{f, t-h}+\varepsilon_{s t}
\end{aligned}
$$

Therefore, in the present study, the optimal hedge ratio is estimated through OLS, GARCH, EGARCH, TARCH, VAR and VECM procedures, which may be constant or time-varying depending upon the property of the series understudy. After estimating the optimal hedge ratio through the aforementioned statistical procedures, the hedging effectiveness of all hedge ratios will be compared and the optimal hedge ratio, which reduces the portfolio variance to a minimum level, would be proposed as an efficient hedge ratio. The efficiency of the optimal hedge ratio would be measured as a percentage decline in portfolio variance as shown in equation (4.11), where $\operatorname{Var}(\mathrm{U})$ and $\operatorname{Var}(\mathrm{H})$ represent the variance of un-hedged and hedged portfolios, respectively. $\sigma_{\mathrm{s}}$ and $\sigma_{\mathrm{f}}$ are the standard deviations of the cash and futures returns, respectively, $\sigma_{\mathrm{s}, \mathrm{f}}$ represents the covariability of the cash and futures returns and $h^{*}$ is the optimal hedge ratio.

Hedge effectiveness $=\frac{\operatorname{Var}(\mathrm{U})-\operatorname{Var}(\mathrm{H})}{\operatorname{Var}(\mathrm{U})}$

$\operatorname{Var}(\mathrm{U})=\sigma_{S}^{2}$

$\operatorname{Var}(\mathrm{H})=\sigma_{s}^{2}+\mathrm{h}^{*^{2}} \sigma_{f}^{2}-2 \mathrm{~h}^{*} \sigma_{\mathrm{s}, \mathrm{f}}$

\section{RESULTS AND ANALYSIS}

Before discussing the optimal hedge ratio estimation results through the various econometric procedures proposed in Section 3 and comparing their efficiency in reducing portfolio risk, it is important to discuss the time series properties of the series under examination. The results in Table 3 indicate important information relating to the summary statistics of futures and cash markets. Table 3 shows that the returns of both futures and cash markets are significantly skewed (negatively skewed in most cases) and their coefficient of kurtosis is significantly different from three, irrespective of crisis period, which implies that futures and cash market returns do not conform to a normal distribution. The null hypothesis that futures and cash market returns follow a normal distribution is further tested through a Jarque-Bera test that is statistically significant, and rejects the null hypothesis for all index futures and cash market returns. Finding asymmetric returns in the futures and cash markets is not a new observation, and summary statistics in the current study are consistent with the findings of Kendall (1953); Fama (1965); Stevenson and Bear (1970); Chen (1996); Reddy (1997) and Kamath (1998).

The type of traders in the two markets may be a potential factor affecting the theoretical distribution of speculative asset returns. It is an established fact that the Indian cash market is predominantly driven by foreign as well as domestic institutional investors, and that retail investors play little role in market movements. On the other hand, in the futures market retail investor participation is very significant and institutional investors have little role to play.7 Therefore, the asymmetric profile of investors in both markets may be a strong determinant for significant asymmetry in basis because institutional investors base their trading decisions on sophisticated analyses undertaken by teams of professionals, whereas retail traders base their decisions on firm-specific or insider information (Thomas, 2006) which can be stale or late, and as a result the timing of trading by the two groups of investors will be different, and hence new information will take time to die out and will cause asymmetric jumps in the conditional volatility of both markets.

Furthermore, Table 4 reports the hedge ratio estimated through Naive, Ederington's Model, ARMA $(p, q)$, VAR, VECM, GARCH $(p, q)$, EGARCH $(p, q)$ and TGARCH $(p, q)$. The hedge ratios estimated through eight models are reported for near month, next month and far month contracts. Three major observations in table 4 can be found. Firstly, hedge ratio coefficients for post crisis period are relatively higher as compared to precrisis period through all the models (except CNXIT near month and next month contracts). The reason for such a result may be due to the contagion effect of the crisis on world economies, including India (Nikkinen, 2013; Bekiros, 2014 and Dufrénot, 2014). Therefore, these results are consistent with the findings of

7 Retail participants drive approximately $60 \%$ of the total trading volume in the Indian equity futures market; however, the participation of institutional traders approximates only $10 \%$ of the total trading volume. For reference, see the Monthly Derivatives Market Update published by National Stock Exchange of India (www. nseindia.com) 
Figlewski (1984) who observes that increases in the co-movement between cash and futures markets leads to a higher hedge ratio. Second, the hedge ratio estimated through Ederington's model, ARMA $(p, q)$, VAR and VECM are constant hedge ratios and their hedging coefficients are relatively smaller than the hedge ratios estimated through time varying models i.e. GARCH, EGARCH and TGARCH. Lastly, hedge ratios for near month futures contracts are relatively higher than the hedge ratio coefficients for next month and far month contracts, which is consistent with the findings of Ederington (1979). From second and third observations, the conclusion can be drawn that the cost of hedging through a constant hedge ratio and near month futures contracts are higher than time varying hedge ratios and far month futures contracts. Furthermore, the coefficients of hedge ratios estimated through VAR and VECM are very close to hedge ratios estimated through Ederington's OLS model, which implies that it incorporates the property of the cost of carry model.

Furthermore, Table 5 reports hedge effectiveness in the form of variance reduction after taking a hedging position by using the estimated hedge ratios. An important observation is that hedging effectiveness was found to be increased during the post-crisis period (except CNXIT near month and next month contracts). Another important observation is that Ederington's OLS model gives the highest hedging effectiveness, whereas the naive hedging model gives the lowest hedging effectiveness among all of the models. Furthermore, near month hedging is found to be more effective than next month and far month hedging. Moreover, there is no significant difference between hedge effectiveness by using the hedge ratio estimated through Ederington's model, ARMA $(p, q)$, VAR, VECM, GARCH $(p, q)$, EGARCH $(p, q)$ and TGARCH $(p, q)$. These findings are consistent with the findings of Maharaj et al. (2008) and Gupta and Singh (2008), which suggests that knowledge of sophisticated econometrical procedures does not help to construct a better portfolio and to improve hedging effectiveness. However, hedging effectiveness estimated by the naive method is significantly low in all cases, irrespective of the financial crisis. Moreover, the probable reason for near month futures contracts being a more efficient hedging instrument than next month and far month futures contracts is the variation of liquidity across these three contracts. The near month futures contracts are more liquid than the next month and far month contracts, and thus near month futures contracts are a more efficient hedging instrument.

Furthermore, negative values for hedge ratio coefficients have been observed for CNXIT far month and
BANKNIFTY far month contracts during the pre-crisis period, which may be due to insufficient trading volume (see Table 6). Another important finding is that the results of the optimal hedge ratio and hedging effectiveness for CNXIT near month and next month contracts have been consistently an exception to the results of the other two indices (i.e. S\&PCNXNIFTY and BANKNIFTY). The reason for such an exception may be due to the fact that the global financial crisis of 2008 adversely affected the business of the Indian IT industry and the sentiments of investors, which is evident from two facts. First, the correlation coefficients of spot and futures price series for CNXIT for all the three types of contracts (i.e. near month, next month and far month) declined in the post-crisis period (see Table 7). Second, the average traded volume for CNXIT contracts show a declining trend after 2007 (see Table 6) which may be due to negative sentiment among investors towards IT stocks, whereas the traded volume for NIFTY and BANKNIFTY continued to rise.

\section{CONCLUSION}

The global financial crisis of 2008 originated in the United States and its spillover effect has been observed over both developed and emerging economies. Equity markets especially witnessed a downfall at the global level and Indian stock markets exhibited enhanced volatility, volatility clustering and mean reversion. Furthermore, volatility and price trends in the market have found to be an important determinant of hedge effectiveness. Also, as mentioned in Section 1, numerous studies have found that the time-to-expiry of futures contracts is an important determinant of hedging effectiveness. However, the Indian derivatives market has observed remarkable growth in futures trading since its inception in the year 2000 and to the best of our knowledge, there have been only a few attempts to study it (see, Bhaduri and Durai, 2007; Rao and Thakur, 2008; Gupta and Singh, 2009 and Pradhan, 2011) all of which have restricted their scope to examining the optimal hedge ratio in the Indian equity futures market. Therefore, the present study is an attempt to examine the impact of the global financial crisis of 2008 and time-to-expiry of futures contracts upon hedging effectiveness by using the three benchmark indices of NSE (S\&PCNXNIFTY, CNXIT and BANKNIFTY).

The returns of both futures and cash markets are found to be significantly negatively skewed and kurtic, which rejects the null hypothesis that market returns are symmetrically distributed among buyers and sellers, implying that the information dissemination 
process is inefficient in the market under study. Furthermore, basis has found to be negatively skewed, which may be due to the existence of a negative correlation between basis and the time-to-expiry of futures contracts.

Hedge ratios have been estimated for near month, next month and far month contracts by employing eight different methodologies: naive, Ederington's Model, VAR, VECM, ARMA $(p, q)$, GARCH(p,q), $\operatorname{EGARCH}(p, q)$ and $\operatorname{TGARCH}(p, q)$ during the pre-crisis and post-crisis periods. The present study finds that hedge ratios during the post-crisis period are relatively higher than during the pre-crisis period, which implies that the cost of hedging has been increased during the post-crisis period. Second, hedge ratios for near month futures contracts are relatively higher than the hedge ratio coefficients for next month and far month contracts, irrespective of the crisis period. Moreover, it has been found that hedge ratios estimated through constant hedging models [Ederington's model, VAR, $\operatorname{VECM}$ and ARMA $(p, q)]$ are relatively smaller than the hedge ratios estimated through time varying models (GARCH, EGARCH and TGARCH) The results of hedging effectiveness suggest that hedging effectiveness has been increased during the post-crisis period. Another important finding is that hedging effectiveness as examined by Ederington's OLS model has been found to be consistently highest for all of the three indices during the pre- and post-crisis periods. Therefore, the study suggests the use of the OLS method for hedging with equity futures. Moreover, the main benefit of using Ederingon's OLS is that it gives the highest hedging effectiveness with the lowest cost (lowest hedge ratio) as compared to hedge ratios estimated by other models. It is also found that near month hedging is more effective than next month and far month hedging. Moreover, the study suggests that the use of any econometric procedure for estimating an optimal hedge ratio does not lead to an improvement in the hedging effectiveness of the portfolio. Moreover, it has been found that due to declines in trading and a reduction in correlation between futures and spot prices for CNXIT, there has been a decline in hedging effectiveness. These findings are also consistent with Gupta and Singh (2009), who suggests that liquidity plays an important role in hedging effectiveness.

The results of the present study are surprisingly inconsistent with the results of most of the studies on short-term and long-term hedging (see, Ederington, 1979; Figlewski, 1984; Kamara and Siegal, 1987; Chen et al., 2002; Chen et al., 2004; In and Kim, 2006 and Juhl et al., 2012), which found that long-term hedging is better than short-term hedging.

The overall conclusion of the study suggests that, first, hedging effectiveness has increased after the crisis, yet is also accompanied by an increase in the cost of hedging; and that second, short period hedging (as identified by near month contracts) in the Indian equity futures market is more effective than long period hedging, the reason for which can be attributed to the fact that near month contracts are more liquid than next month or / and far month contracts, while short-term hedging has found to be more costly than long-term hedging.

\section{REFERENCES}

Abdulnasser Hatemi-Ja, Eduardo Roca. 2006. Calculating the Optimal Hedge Ratio Constant, Time Varying and the Kalman Filter Approach. Applied Economics Letters 13: 293-299.

Aggarwal, Raj, and Andrea L. DeMaskey. 1997. Using Derivatives in Major Currencies for Cross-Hedging Currency Risks in Asian Emerging Markets. The Journal of Futures Markets 17 (7): 781-796.

Ali, R. and Afzal, M. 2012. Impact of the Global Financial Crisis on Stock Markets: Evidence from Pakistan and India. Journal of Business Management and Economics 3 (7): 275-282.

Alizadeh, Amir, and Nikos Nomikos. 2004. A Markov Regime Switching Approach for Hedging Stock Indices. The Journal of Futures Market 24 (7): 649-674.

Al-Rjoub, S and Azzam, H. 2012. Financial Crises, Stock Returns and Volatility in an Emerging Stock Market: The Case of Jordan. Journal of Economic Studies 39 (2): 178 $-211$.

Anshuman, R. \& Goswami, R. 2000. Day of the Week Effects on the Bombay Stock Exchange. Research Paper Presented in UTI Capital Market Conference Proceedings: 1-33.

Barua, S. K. 1981. The Short-run Price Behavior of Securities: Some Evidence on Efficiency of Indian Capital Market. Vikalpa, 16 (2): 93-100.

Bekiros, S. D. 2014. Contagion, Decoupling and the Spillover Effects of the US Financial Crisis: Evidence from the BRIC Markets. International Review of Financial Analysis 33: 58-69.

Bhaduri, Saumitra N, and S. Raja Sethu Durai. 2007. Optimal Hedge Ratio and Hedging Effectiveness of Stock Index Futures: Evidence from India. NSE Research Paper. NSE, India.

Bhargava, Vivek, and D.K. Malhotra. 2007. Determining the Optimal Hedge Ratio: Evidence from Cotton and Soybean Markets. Journal of Business and Economic Studies 13 (1): 38-57.

Bose, S. 2006. The Indian Derivatives Market Revisited, ICRA Bulletin: Money and Finance, Jan-July, 2006: 81-112. 
Brooks, Chris, Ales Cerny, and Joelle Miffre. 2012. Optimal Hedging with Higher Moments. The Journal of Futures Markets 32 (10): 909-944.

Butterworth, Darren, and Phil Holmes. 2001. The Hedging Effectiveness of Stock Index Futures: Evidence for the FTSE-100 and FTSE-Mid250 Indexes Traded in the UK. Applied Financial Economics 11: 57-68.

Carlton, D.W. 1984. Futures Markets: Their Purpose, Their History, Their Successes and Failures. The Journal of Futures Markets 4 (3): 237-271.

Castelino, M. G. 1989. Basis Volatility: Implications for Hedging. Journal of Financial Research 12 (2): 157-172.

Castelino, Mark G. 1992. Hedge Effectiveness: Basis Risk and Minimum-Variance Hedging. The Journal of Futures Markets 20 (1): 89-103.

Chan, Leo, and Donald Lien. 2001. Cash Settlement and Price Discovery in Futures Market. Quarterly Journal of Business and Economics 40 (3/4): 65-77.

Chang, Eric, Ray Y. Chou, and Edward Nelling. 2000. Market Volatility and the Demand for Hedging in Stock Index Futures. The Journal of Futures Markets 20 (2): 105-125.

Chaudhuri, S. K. 1991. Short-Run Behavior of Industrial Share Price Indices: An Empirical Investigation. Prajnan 22 (2): 169-183.

Chen, P. 1996. A Random-Walk or Color-Chaos on the Stock Market? Time- Frequency Analysis of S \& P Indexes. Studies in Nonlinear Dynamics \& Econometrics1 (2): 87-103.

Chen, Chao-Chun, and Wen-Jen Tsay. 2011. A Markov Regime-Switching ARMA Approach for Hedging Stock Indices. The Journal of Futures Market 31 (2): 165-191.

Chen, Sheng-Syan, Cheng-Few Lee, and Keshab Shrestha. 2004. An Empirical Analysis of the Relationship Between the Hedge Ratio and Hedging Horizon: A Simultaneous Estimation of the Short- and Long-Run Hedge Ratios. The Journal of Futures Markets 24 (4): 359-386.

Chen, Sheng-Syan, Cheng-Few Lee, and Keshab Shrestha. 2001. On a Mean-Generalized Semivariance Approach to Determining the Hedge Ratio. The Journal of Futures Markets 21 (6): 581-598.

Cox, Charles C. 1976. FuturesTrading and Market Information. The Journal of Polotical Economy 84 (6): 1215-1237.

Crowder, W. J. and Phengpis, C. 2005. Stability of the S\&P500 Futures Market Efficiency Conditions. Applied Financial Economics 15: 855-866.

Diagler, R. T. and Wiley, M. K. 1999. The Impact of Trader Type on the Futures Volatility-Volume Relation. The Journal of Finance 54 (6): 2297-2316.

Dimson, E. and Mussavian, M. 1998. A Brief History of Market Efficiency. European Financial Management 4 (1): 91-104.

Dufrénot, G and Keddad, B. 2014. Spillover Effects of the 2008 Global Financial Crisis on the Volatility of the Indian Equity Markets: Coupling or Uncoupling? A study on
Sector-Based Data. International Review of Financial Analysis 33: 17-32.

Ederington, Louis H. 1979. The Hedging Performance of the New Futures Markets. The Journal of Finance 34 (1): 157-170.

Evans, T. 2006. Efficiency Tests of the U.K. Financial Futures Markets and the Impact of Electronic Trading Systems. Applied Financial Economics16: 1273-1283.

Fama, E. F. 1965, The Behavior of Stock-Market Prices. The Journal of Business38 (1): 34-105.

Fama, E. F. 1970. Efficient Capital Markets: A Review of Theory and Empirical Work. Journal of Finance25 (2): 383-417.

Fama, E. F. and French, K. R. 1987. Commodity Futures Prices: Some Evidence on Forecast Power, Premiums, and the Theory of Storage. Journal of Business 60 (1): 55-73.

Figlewski, Stephen. 1984. Hedging Performance and Basis Risk in Stock Index Futures. The Journal of Finance 39 (3): 657-669.

Floros, Christos, and Dimitrios V. Vougas. 2004. Hedge Ratio in Greek Stock Index Futures Market. Applied Financial Economics 14: 1125-1136.

Floros, Christos, and Dimitrios V. Vougas. 2006. Hedging Effectiveness in Greek Stock Index Futures Market, 19992001. International Research Journal of Finance and Economics 5: 7-18.

Garbade, Kenneth D, and Willaim L. Silber. 1983. Price Movement and Price Discovery in Futures and Cash Markets. The Review of Economics and Statistics 65 (2): 289-297.

Gupta, K. and Singh, B. 2006a. Random Walk and Indian Equity Futures Market. ICFAI Journal of Derivatives Market III (3): 23-42.

Gupta, K. and Singh, B. 2006b. Investigating the Price Discovery Efficiency of Indian Equity Futures Market. PARADIGM X (2): 33-45.

Gupta, K. and Singh, B. 2009. Estimating the Optimal Hedge Ratio in Indian Equity Futures Market. Journal of Financial Risk Management VI (3 \& 4): 38-98.

Gupta, O. P. 1985. Behavior of Share Prices in India: A Test of Market Efficiency. National Publications, New Delhi.

Holmes, Phil. 1995. Ex Ante Hedge Ratios and the Hedging Effectiveness of the FTSE-100 Stock Index Futures Contracts. Applied Economics Letters 2: 56-59.

In, Francis, and Sangbae Kim. 2006. The Hedge Ratio and the Empirical Relationship Between the Stock and Futures Markets: A New Approach Using Wavelet Analysis. The Journal of Business 79 (2): 799-820.

Johnson, L. 1960. The Theory of Hedging and Speculation in Commodity Futures. Review of Economic Studies 27: 139-151.

Joshi, P. 2012. Financial Crisis and Volatility Behavior of Stock Markets of Asia. Quest-Journal of Management and Research 2 (2): 35-44. 
Juhl, Ted, Ira G. Kawaller, and Paul D. Koch. 2012. The Effect of the Hedge Horizon on Optimal Hedge Size and Effectiveness When Prices are Cointegrated. The Journal of Futures Markets 32 (9): 837-876.

Kamara, Avraham. 1982. Issues in Futures Markets: A Survey. The Journal of Futures Markets 2 (3): 261-294.

Kamara, Avraham, and Andrew F. Siegel. 1987. Optimal Hedging in Futures Markets with Multiple Delivery Specifications. The Journal of Finance 42 (4): 1007-1021.

Kamath, R. R., Chakornpipat, R. and Chatrath, A. 1998. Return Distribution and the Day-of-the-Week Effects in the Stock Exchange of Thailand. Journal of Economics and Finance22 (2-3): 97-106.

Karim, B. A., Jais, M. and Karim, S. A. A. 2011. The Subprime Crisis and Stock Index Futures Markets Integration. The Journal of Risk Finance12 (5): 400 - 408.

Karpoff, J. M. 1987. The Relation Between Price Changes and Trading Volume: A Survey. Journal of Financial and Quantitative Analysis22 (1): 109-126.

Kendall, M. G. and Hill, B. A. 1953. The Analysis of Economic Time Series Part I. Prices. Journal of Royal Statistical Society 9: 11-25.

Kenourgios, Dimitris, Aristeidis Samitas, and Panagiotis Drosos. 2008. Hedge Ratio Estimation and Hedging Effectiveness:The Case of the S\&P 500 Stock Index Futures Contract. International Journal of Risk Assessment and Management 9 (1/2): 121-134.

King, M. A. and Wadhwani, S. 1990. Transmission of Volatility between Stock Markets. Review of Financial Studies, 3 (1): 5-33.

Kofman, Paul, and McGlenchy Patrick. 2005. Structurally Sound Dynamic Index Futures Hedging. The Journal of Futures Markets 25 (12): 1173-1202.

Kroner, Kenneth F., and Jahangir Sultan. 1993. TimeVarying Distributions and Dynamics Hedging with Foreign Currency Futures. The Journal of Financial and Quantitative Analysis 28 (4): 535-551.

Kumar, S.S.S. 2012. Financial Derivatives. New Delhi: PHI Learning Private Limited.

Lee, Hsiang Tai, and Jonathan K. Yoder. 2007. A Bivariate Markov Regime Switching GARCH Approach to Estimate Time Varying Minimum Variance Hedge Ratios. Applied Economics 39: 1253-1265.

Lien, Donald. 2005. A Note on the Superiority of the OLS Hedge Ratio. The Journal of Futures Markets 25 (11): 1121-1126.

Lien, Donald, and Xiangdong Luo. 1994. Multiperiod Hedging in the Presence of Conditional Heteroskedasticity. The Journal of Futures Markets 14 (8): 927-955.

Longin, F. M., and Solnik, B. 2001. Extreme Correlation of International Equity Markets. Journal of Finance 56: 649-676.

Lypny, G. and Powalla, M. 1998. The Hedging Effectiveness of DAX Futures. European Journal of Finance 4: 345-355.
Maharaj, E. A., Moosa, I., Dark, J. and Silvapulle, P. 2008. Wavelet Estimation of Asymmetric Hedge Ratios: Does Econometric Sophistication Boost Hedging Effectiveness?. International Journal of Business and Economics 7 (3): 213-230.

Majid, M. S. A. and Kassim, S. H. 2009. Impact of the 2007 US Financial Crisis on the Emerging Equity Markets. International Journal of Emerging Markets 4 (4), 341-57.

Mangala, D. and Mittal, R. K. 2005. The Efficiency of the Indian Stock Market: An Evidence of Day-of-the-Week Effect. Gyan - A Bi-Annual Journal of Management \& Technology 1 (1): 3-8.

Marisetty, V. B. 2003. Measuring Productive Efficiency of Stock Exchanges using Price Adjustment Coefficients. International Review of Finance4 (1-2): 79-99.

Mazumder, M. I. and Ahmad, N. 2010. Greed, Financial Innovation or Laxity of Regulation?. Studies in Economics and Finance 27 (2): 110 - 134.

Mishra, B. 1999. Presence of Friday Effect in Indian Stock Market. Paradigm3 (2): 57-64.

Moolman, H. C. 2004. An Asymmetric Econometric Model of the South African Stock Market. Ph. D Dissertation, University of Pretoria.

Monoyios, M. and Sarno, L. 2002. Mean Reversion in Stock Index Futures Markets: A Nonlinear Analysis. The Journal of Futures Markets22( 4): 285-314.

Moschini, GianCarlo, and Robert J. Myers. 2002. Testing for Constant Hedge Ratios in Commodity Markets: A Multivariate GARCH Approach. Journal of Empirical Finance 9: 589-603.

Myers, Robert J. 1991. Estimating Time-Varying Optimal Hedge Ratios on Futures Markets. The Journal of Futures Markets 20 (1): 73-87.

Nath, G. C. 2002. Long Memory and Indian Stock Market An Empirical Evidence. Research Paper Presented in UTI Capital Market Conference Proceedings, pp. 1-20.

Nelson, D. B. 1991. Conditional Heteroskedasticity in Asset Returns: A New Approach. Econometrica59: 347-370.

Neuberger, Anthony. 1999. Hedging Long-Term Exposures with Multiple Short-Term Futures Contracts. The Review of Financial Studies 12 (3): 429-459.

Nikkinen, J., Saleem, K. and Martikainen, M. 2013. Transmission Of The Subprime Crisis: Evidence From Industrial And Financial Sectors Of BRIC Countries. The Journal of Applied Business Research29 (5): 1469-1478.

Pant, B. and Bishnoi, R. T. 2001. Testing Random Walk Hypothesis for Indian Stock Market Indices. Research Paper Presented in UTI Capital Market Conference Proceedings, pp. 1-15.

Park, Tae H., and Lorne N. Switzer. 1995. Time-Varying Distributions and the Optimal Hedge Ratios for Stock Index Futures. Applied Financial Economics 5: 131-137.

Pattarin, Franceso, and Riccardo Ferretti. 2004. The Mib30 Index and Futures Relationship: Econometric Analysis 
and Implications for Hedging. Applied Financial Economics 14: 1281-1289.

Rao, S. V. D. and Thakur, S. 2008. Optimal Hedge Ratio and Hedge Efficiency: An Empirical Investigation of Hedging in Indian Derivatives Market. Available at https://www. soa.org/library/monographs/other-monographs/2008/ april/mono-2008-m as08-1-thakur.pdf (accessed January 21, 2014).

Rao, K. N. 1988. Stock Market Efficiency: the Indian Experience, Proceedings of National Seminars on Indian Securities Markets: Thrust and Challenges, March 24-26, University of Delhi, 1988: New Delhi.

Ranjan, R. and Padhye, A. 2000. Market Anomalies in Emerging Markets: Revisiting the Calendar Effect in Stock Prices. ICICI Research Centre. Org., pp. 1-19.

Pradhan, K. C. 2011. The Hedging Effectiveness of Stock Index Futures: Evidence for the S\&P CNX Nifty Index Traded in India. South East European Journal of Economics \& Business 6 (1):111-123.

Reddy, S. Y. 1997. Efficiency of Indian Stock Markets: An Empirical Analysis of Weak-Form EMH of the BSE. Research Paper Presented in UTI Capital Market Conference Proceedings, pp. 91-115.

Sharma, J. L. 1983. Efficient Capital Markets and Random Character of Stock Price Behavior in Developing Economy.Indian Journal of Economics 63: 395- 419.

Singhania, M. and Anchalia, J. 2013. Volatility in Asian Stock Markets and the Global Financial Crisis. Journal of Advances in Management Research 10 (3): 333 - 351.

Stein, Jerome L. 1961. The Simultaneous Determination of Spot and Futures Prices. The American Economic Review 51 (5): 1012-1025.
Stevenson, A. R. and Bear, M. R. 1970. Commodity Futures: Trends or Random Walks?. The Journal of Finance25 (1): 65-81.

Stoll, H. R. and Whaley, R. E. 1990. Dynamics of Stock Index and Stock Index Futures Returns. Journal of Financial and Quantitative Analysis 25 (4): 441-468.

Sugimoto, K., Matsuki, T. and Yoshida, Y. 2014. The Global Financial Crisis: An analysis of the Spillover Effects on African Stock Markets. Emerging Markets Review 21: 201-233.

Telser, Lester G. 1981. Why There are Organised Futures Markets. Journal of Law and Economics 24 (1): 1-22.

Theobald, Michael, and Yallp, Peter. 2001. Mean Reversion and Basis Dynamics. The Journal of Futures Markets 21 (9): 797-818.

Theobald, Michael, and Peter Yallup. 1997. Hedging Ratios and Cash / Futures Market Linkages. The Journal of Futures Markets 17 (1): 101-115.

Woking, Holbrook. 1953. Futures Trading and Hedging. American Economic Review 43: 314-343.

Working, Holbrook. 1962. New Concepts Concerning Futures Markets and Prices. The American Economic Review 52 (3): 431-459.

Yang, Ming Jing, and Yi-Chuan Lai. 2009. An Out-of-Sample Comparative Analysis of the Hedging Performance of Stock Index Futures: Dynamic Versus Static Hedging. Applied Financial Economics 19: 1059-1072.

Zeng, T. 2001. Mean Reversion and the Comovement of Equilibrium Spot and Futures Prices: Implications from Alternative Data-Generating Processes. The Journal of Futures Markets 21 (8): 769-796. 
Table 2: Literature Review of Hedging Effectiveness

\begin{tabular}{|c|c|c|c|c|c|}
\hline $\begin{array}{l}\text { Author } \\
\text { (year of study) }\end{array}$ & $\begin{array}{l}\text { Market } \\
\text { understudy }\end{array}$ & Symbols & $\begin{array}{l}\text { Sample } \\
\text { period }\end{array}$ & Methodology & Hedging effectiveness \\
\hline $\begin{array}{l}\text { Ederington } \\
\text { (1979) }\end{array}$ & U.S.A. & $\begin{array}{l}\text { GNMA and T-Bill } \\
\text { Futures Markets }\end{array}$ & $\begin{array}{l}\text { Jan. } 1976 \text { to } \\
\text { Dec. } 1977 \\
\text { and Mar. } \\
1976 \text { to Dec. } \\
1977\end{array}$ & OLS & $\begin{array}{l}\text { Futures hedging is better for longer } \\
\text { periods than short periods }\end{array}$ \\
\hline $\begin{array}{l}\text { Figlewski } \\
\text { (1984) }\end{array}$ & U.S.A. & $\begin{array}{l}\text { S\&P500, NYSE, } \\
\text { AMEX, NASDAQ, } \\
\text { DOW }\end{array}$ & $\begin{array}{l}\text { June } 1982 \text { to } \\
\text { Sept } 1983\end{array}$ & OLS & $\begin{array}{l}\text { Basis risk disturbs hedging effective- } \\
\text { ness, therefore one week hedging is } \\
\text { better than overnight hedging }\end{array}$ \\
\hline $\begin{array}{l}\text { Kamara and } \\
\text { Siegel (1987) }\end{array}$ & U.S.A. & $\begin{array}{l}\text { Soft Wheat and } \\
\text { Hard Wheat }\end{array}$ & $\begin{array}{l}\text { Jan. } 1970 \text { to } \\
\text { March } 1981\end{array}$ & OLS & $\begin{array}{l}\text { Far period hedging is better than } \\
\text { near to expiration period }\end{array}$ \\
\hline Myers (1991) & U.S.A. & Wheat Futures & $\begin{array}{l}\text { June } 1977 \text { to } \\
\text { May } 1983\end{array}$ & $\begin{array}{l}\text { OLS and } \\
\text { BGARCH }\end{array}$ & $\begin{array}{l}\text { Time varying hedge ratios are better } \\
\text { than constant hedge ratios. }\end{array}$ \\
\hline $\begin{array}{l}\text { Kroner and } \\
\text { Sultan (1993) }\end{array}$ & U.S.A. & $\begin{array}{l}\mathrm{BP}, \mathrm{CD}, \mathrm{GM}, \mathrm{JY} \text { and } \\
\mathrm{SF}\end{array}$ & $\begin{array}{l}\text { Feb. } 1985 \text { to } \\
\text { Feb. } 1990\end{array}$ & $\begin{array}{l}\text { Naive, OLS, } \\
\text { ECM and } \\
\text { ECM-GARCH }\end{array}$ & $\begin{array}{l}\text { Time varying error correction meth- } \\
\text { odology takes care of transaction } \\
\text { costs,and thus outperforms other } \\
\text { methodologies. }\end{array}$ \\
\hline $\begin{array}{l}\text { Lien and Luo } \\
\text { (1994) }\end{array}$ & U.S.A. & $\begin{array}{l}\mathrm{BP}, \mathrm{CD}, \mathrm{GM}, \mathrm{JY} \text { and } \\
\mathrm{SF}\end{array}$ & $\begin{array}{l}\text { March } 1980 \\
\text { to Dec. } 1988\end{array}$ & $\begin{array}{l}\text { OLS, BGARCH, } \\
\text { ECM }\end{array}$ & $\begin{array}{l}\text { If a trader is extremely risk aversee, } \\
\text { both constant and time varying } \\
\text { hedge ratios are equally efficient, } \\
\text { whereas to achieve utility maximi- } \\
\text { zation the objective GARCH hedge } \\
\text { ratio is most efficient. }\end{array}$ \\
\hline Homles (1995) & U.K. & $\begin{array}{l}\text { FTSE100 Futures } \\
\text { and FTSE100 } \\
\text { Index }\end{array}$ & $\begin{array}{l}\text { July } 1984 \text { to } \\
\text { June } 1992\end{array}$ & $\begin{array}{l}\text { Ex-Post } \\
\text { MVHR, Ex- } \\
\text { Ante MVHR } \\
\text { and Beta }\end{array}$ & $\begin{array}{l}\text { MVHR based upon historical data is } \\
\text { better }\end{array}$ \\
\hline $\begin{array}{l}\text { Park and } \\
\text { Switzer (1995) }\end{array}$ & $\begin{array}{l}\text { U.S.A. and } \\
\text { Canada }\end{array}$ & $\begin{array}{l}\text { S\&P500, MMI and } \\
\text { TSE35 }\end{array}$ & $\begin{array}{l}\text { June } 1988 \text { to } \\
\text { Dec. } 1991\end{array}$ & $\begin{array}{l}\text { Naive, OLS, } \\
\text { OLS with } \\
\text { Cointegration } \\
\text { and BGARCH } \\
\end{array}$ & $\begin{array}{l}\text { Time varying hedge ratios are supe- } \\
\text { rior to constant hedge ratios. }\end{array}$ \\
\hline $\begin{array}{l}\text { Aggarwal and } \\
\text { Demaskey } \\
\text { (1997) }\end{array}$ & $\begin{array}{l}\text { Hong Kong, } \\
\text { South Korea, } \\
\text { Singapore, } \\
\text { Taiwan, } \\
\text { Indonesia, } \\
\text { Philippines } \\
\text { and Thailand }\end{array}$ & $\begin{array}{l}\mathrm{BP}, \mathrm{CD}, \mathrm{GM}, \mathrm{JY} \text { and } \\
\mathrm{SF}\end{array}$ & $\begin{array}{l}\text { Jan. } 1983 \text { to } \\
\text { Dec. } 1992\end{array}$ & $\begin{array}{l}\text { Naive and } \\
\text { OLS }\end{array}$ & Cross hedging is beneficial. \\
\hline $\begin{array}{l}\text { Theobald and } \\
\text { Yallup (1997) }\end{array}$ & U.K. & $\begin{array}{l}\text { FTSE100 Futures } \\
\text { and FTSE100 } \\
\text { Index }\end{array}$ & $\begin{array}{l}\text { Jan. } 1985 \text { to } \\
\text { Dec. } 1995\end{array}$ & OLS & $\begin{array}{l}\text { Futures contracts can provide hedg- } \\
\text { ing benefits only when both markets } \\
\text { do not suffer with the problem of } \\
\text { non-synchronous trading. }\end{array}$ \\
\hline $\begin{array}{l}\text { Neuberger } \\
(1999)\end{array}$ & U.S.A & Crude oil futures & $\begin{array}{l}\text { July } 1986 \text { to } \\
\text { Aug. } 1997\end{array}$ & $\begin{array}{l}\text { Ex-ante and } \\
\text { OLS }\end{array}$ & $\begin{array}{l}\text { Rollover of futures contracts adds to } \\
\text { hedging effectiveness }\end{array}$ \\
\hline $\begin{array}{l}\text { Theobald and } \\
\text { Yallup (2001) }\end{array}$ & U.K. & $\begin{array}{l}\text { FTSE-100 Index } \\
\text { Futures and FTSE- } \\
100 \text { Index }\end{array}$ & $\begin{array}{l}\text { Jan } 28,1999 \\
\text { to Dec 3, } \\
1999\end{array}$ & $\begin{array}{l}\text { Autocorr- } \\
\text { elation }\end{array}$ & $\begin{array}{l}\text { Partial adjustment coefficients } \\
\text { induce mean reversion in the basis } \\
\text { change, which are highest at shorter } \\
\text { intervals ( }<15 \text { mins ) }\end{array}$ \\
\hline $\begin{array}{l}\text { Butterworth } \\
\text { and Holmes } \\
(2001)\end{array}$ & U.K. & $\begin{array}{l}\text { FTSE-100 Index } \\
\text { Futures and FTSE- } \\
\text { mid } 250 \text { Index }\end{array}$ & $\begin{array}{l}\text { Feb. } 1994 \text { to } \\
\text { Dec. } 1996\end{array}$ & OLS, LTS & $\begin{array}{l}\text { A new contract is more effective } \\
\text { in hedging ITCs than established } \\
\text { FTSE100 contracts. }\end{array}$ \\
\hline
\end{tabular}




\begin{tabular}{|c|c|c|c|c|c|}
\hline $\begin{array}{l}\text { Chen et al., } \\
(2001)\end{array}$ & U.S.A. & S\&P500 Futures & $\begin{array}{l}\text { April } 1982 \text { to } \\
\text { Dec. } 1991\end{array}$ & $\begin{array}{l}\text { M-GSV, MEG, } \\
\text { Sharpe, OLS } \\
\text { and Standard } \\
\text { mean } \\
\text { variance }\end{array}$ & $\begin{array}{l}\text { M-GSV minimizes the portfolio vari- } \\
\text { ance by maximum }\end{array}$ \\
\hline $\begin{array}{l}\text { Moschini and } \\
\text { Myers (2002) }\end{array}$ & U.S.A. & Corn Futures & $\begin{array}{l}\text { Jan. } 1976 \text { to } \\
\text { June } 1997\end{array}$ & \begin{tabular}{|l|} 
BEKK, GARCH \\
and OLS \\
\end{tabular} & Supports time varying hedge ratio \\
\hline $\begin{array}{l}\text { Chen et al., } \\
(2002)\end{array}$ & Taiwan & $\begin{array}{l}\text { TAIFEXTAIEX- } \\
\text { TAIEX AND } \\
\text { SGXMSCI-MSCI } \\
\end{array}$ & $\begin{array}{l}\text { July } 1998 \text { to } \\
\text { July } 2000\end{array}$ & $\begin{array}{l}\text { OLS, Bayesian } \\
\text { Approach }\end{array}$ & $\begin{array}{l}\text { Hedging effectiveness observes a } \\
\text { positive relationship with hedging } \\
\text { horizon. }\end{array}$ \\
\hline $\begin{array}{l}\text { Alizadeh and } \\
\text { Nomikos (2004) }\end{array}$ & U.S.A. and U.K. & $\begin{array}{l}\text { S\&P500 Futures } \\
\text { and S\&P500 Index } \\
\text { and FTSE100 } \\
\text { Futures and } \\
\text { FTSE100 Index }\end{array}$ & $\begin{array}{l}\text { May } 1984 \text { to } \\
\text { March } 2001\end{array}$ & $\begin{array}{l}\text { OLS, ECM, } \\
\text { GARCH and } \\
\text { Markov } \\
\text { Regime } \\
\text { Switching } \\
\text { Models } \\
\end{array}$ & $\begin{array}{l}\text { By allowing the hedge ratio to be } \\
\text { dependent upon the state of market, } \\
\text { one may obtain a more efficient } \\
\text { hedge ratio. }\end{array}$ \\
\hline $\begin{array}{l}\text { Floros and } \\
\text { Vougas (2004) }\end{array}$ & Greece & $\begin{array}{l}\text { FTSE/ASE- } 20 \\
\text { index and FTSE/ } \\
\text { ASE-40 index }\end{array}$ & & $\begin{array}{l}\text { OLS, VECM } \\
\text { and M-GARCH }\end{array}$ & $\begin{array}{l}\text { The M-GARCH model provides the } \\
\text { best hedging ratios. }\end{array}$ \\
\hline $\begin{array}{l}\text { Chen et al., } \\
(2004)\end{array}$ & $\begin{array}{l}\text { U.S.A., U.K., } \\
\text { Canada, } \\
\text { Japan, } \\
\text { Australia }\end{array}$ & $\begin{array}{l}7 \text { Stock Market } \\
\text { Index futures, } \\
11 \text { Commodity } \\
\text { futures, } 2 \text { metals } \\
\text { and } 5 \text { currencies }\end{array}$ & $\begin{array}{l}\text { June } 1982 \text { to } \\
\text { Dec. } 1997\end{array}$ & OLS & $\begin{array}{l}\text { Short-run hedge ratio is significantly } \\
<1 \text { but as the hedge horizon in- } \\
\text { creases it approaches } 1 \text { while hedg- } \\
\text { ing effectiveness also improves. }\end{array}$ \\
\hline $\begin{array}{l}\text { Pattarin and } \\
\text { Ferretti (2004) }\end{array}$ & Italy & $\begin{array}{l}\text { Fib30 and Mib30 } \\
\text { Index }\end{array}$ & $\begin{array}{l}\text { Nov. } 1994 \text { to } \\
\text { Sept. } 2002\end{array}$ & $\begin{array}{l}\text { Naive, OLS, } \\
\text { ECM, GARCH, } \\
\text { EWMA }\end{array}$ & $\begin{array}{l}\text { Time varying hedge ratio based } \\
\text { upon EWMA is better }\end{array}$ \\
\hline Lien (2005) & $\mathrm{N} / \mathrm{A}$ & N/A & N/A & OLS, ECM & $\begin{array}{l}\text { OLS is a superior model over error } \\
\text { correction model. }\end{array}$ \\
\hline $\begin{array}{l}\text { Kofman and } \\
\text { McGlenchy } \\
(2005)\end{array}$ & Hong Kong & HSIF and HIS & $\begin{array}{l}\text { Jan. } 1994 \text { to } \\
\text { July } 2003\end{array}$ & $\begin{array}{l}\text { Naive, } \\
\text { Expanding } \\
\text { window, } \\
\text { Rolling win- } \\
\text { dow, EWLS } \\
\text { and ROC } \\
\end{array}$ & $\begin{array}{l}\text { Dynamic hedging is better than } \\
\text { constant hedging. }\end{array}$ \\
\hline $\begin{array}{l}\text { Hatemi and } \\
\text { Roca (2006) }\end{array}$ & Australia & $\mathrm{MSCl}$ index & $\begin{array}{l}\text { Jan } 1,1988 \text { to } \\
\text { Sept } 8,2001\end{array}$ & $\begin{array}{l}\text { Kalman Filter } \\
\text { Approach }\end{array}$ & $\begin{array}{l}\text { Kalman Filter Approach is statisti- } \\
\text { cally more efficient and has better } \\
\text { forecasting properties. }\end{array}$ \\
\hline $\begin{array}{l}\text { Floros and } \\
\text { Vougas (2006) }\end{array}$ & Greece & $\begin{array}{l}\text { FTSE/ASE20 Index } \\
\text { Futures and FTSE/ } \\
\text { ASE Mid } 40 \text { Index } \\
\text { Futures }\end{array}$ & $\begin{array}{l}\text { Aug. } 1999 \text { to } \\
\text { Aug. } 2001 \\
\text { and Jan. } 200 \\
\text { to Aug. } 2001 \\
\end{array}$ & $\begin{array}{l}\text { OLS, ECM, } \\
\text { VECM and } \\
\text { BGARCH }\end{array}$ & $\begin{array}{l}\text { Time varying hedge ratio is superior } \\
\text { to constant hedge ratios }\end{array}$ \\
\hline $\begin{array}{l}\text { In and Kim } \\
(2006)\end{array}$ & U.S.A. & $\begin{array}{l}\text { S\&P500 Futures } \\
\text { and S\&P500 Index }\end{array}$ & $\begin{array}{l}\text { April } 1982 \text { to } \\
\text { Dec. } 2001\end{array}$ & $\begin{array}{l}\text { Wavelet } \\
\text { Analysis }\end{array}$ & $\begin{array}{l}\text { Hedging effectiveness does not only } \\
\text { depend upon hedging horizon: risk } \\
\text { aversion of hedger also affects hedg- } \\
\text { ing effectiveness. Investors with low } \\
\text { risk aversion have short-run HE and } \\
\text { vice versa. }\end{array}$ \\
\hline $\begin{array}{l}\text { Bhaduri and } \\
\text { Durai (2007) }\end{array}$ & India & $\begin{array}{l}\text { Nifty Index } \\
\text { Futures and Nifty } \\
\text { Index }\end{array}$ & $\begin{array}{l}\text { Sept. } 2000 \text { to } \\
\text { Aug. } 2005\end{array}$ & $\begin{array}{l}\text { OLS, ECM, } \\
\text { BVAR and } \\
\text { M-GARCH }\end{array}$ & $\begin{array}{l}\text { (i) GARCH model performs better in } \\
\text { the long-run whereas OLS is a better } \\
\text { measure during the short-run. } \\
\text { (ii) Time-varying hedge ratios are } \\
\text { superior to constant HR }\end{array}$ \\
\hline
\end{tabular}




\begin{tabular}{|c|c|c|c|c|c|}
\hline $\begin{array}{l}\text { Bhargava and } \\
\text { Malhotra (2007) }\end{array}$ & U.S.A. & $\begin{array}{l}\text { Cotton and } \\
\text { Soybeans Futures }\end{array}$ & $\begin{array}{l}\text { Jan. } 1994 \text { to } \\
\text { Dec. } 1999 \\
\text { and Jan. } 1995 \\
\text { to Dec. } 2000\end{array}$ & \begin{tabular}{|l|} 
Traditional \\
regression \\
method, \\
Modified \\
regression \\
method and \\
ECM
\end{tabular} & $\begin{array}{l}\text { Traditional regression method per- } \\
\text { forms better than others }\end{array}$ \\
\hline $\begin{array}{l}\text { Lee and Yoder } \\
\text { (2007) }\end{array}$ & U.K. & $\begin{array}{l}\text { Corn and Nickel } \\
\text { Futures and Spot } \\
\text { Markets }\end{array}$ & $\begin{array}{l}\text { Jan. } 1991 \text { to } \\
\text { Dec. } 2004\end{array}$ & $\begin{array}{l}\text { RS-BEKK, } \\
\text { BEKK and OLS }\end{array}$ & $\begin{array}{l}\text { Time varying hedge ratio performs } \\
\text { better. }\end{array}$ \\
\hline $\begin{array}{l}\text { Rao and Thakur } \\
(2008)\end{array}$ & India & $\begin{array}{l}\text { Nifty Index } \\
\text { Futures and Nifty } \\
\text { Index Options }\end{array}$ & $\begin{array}{l}\text { Jan. 1, 2002 } \\
\text { to Mar. 28, } \\
2002\end{array}$ & HKM, JSE, fBN, & $\begin{array}{l}\text { HKM methodology yields better } \\
\text { Optimal Hedge ratio than JSE meth- } \\
\text { odology in the Indian Futures Market }\end{array}$ \\
\hline $\begin{array}{l}\text { Kenourgios et } \\
\text { al., (2008) }\end{array}$ & U.S.A & $\begin{array}{l}\text { S\&P500 stock } \\
\text { Index futures }\end{array}$ & \begin{tabular}{|l} 
July 3,1992 \\
to June 30, \\
2002
\end{tabular} & $\begin{array}{l}\text { OLS, ECM, } \\
\text { GARCH, } \\
\text { EGARCH }\end{array}$ & $\begin{array}{l}\text { ECM is superior to other models and } \\
\text { remains stable over time. }\end{array}$ \\
\hline $\begin{array}{l}\text { Gupta and } \\
\text { Singh (2009) }\end{array}$ & India & \begin{tabular}{|l|} 
Nifty Index \\
Futures, Nifty \\
Index, Nifty Stock \\
Futures and Nifty \\
Stock \\
\end{tabular} & 2003-07 & $\begin{array}{l}\text { VAR, VECM, } \\
\text { GARCH, } \\
\text { EGARCH, } \\
\text { TARCH and } \\
\text { OLS } \\
\end{array}$ & $\begin{array}{l}\text { (i) VAR and VECM reduced the } \\
\text { portfolio variance by the maximum } \\
\text { extent } \\
\text { (ii) Hedging through liquid futures } \\
\text { contract involves low hedging cost. }\end{array}$ \\
\hline $\begin{array}{l}\text { Yang and Lai } \\
(2009)\end{array}$ & U.S.A and U.K. & \begin{tabular}{|l} 
DJIA, \\
S\&P500, \\
Nasdaq100, \\
FTSE100, CAC40, \\
DAX30 \\
And Nikkei225 \\
\end{tabular} & $\begin{array}{l}\text { Nov. } 30,1998 \\
\text { to } \\
\text { Feb. 20, } 2003\end{array}$ & $\begin{array}{l}\text { GJR-EC- } \\
\text { GARCH, } \\
\text { GJR-GARCH, } \\
\text { EC-OLS AND } \\
\text { OLS }\end{array}$ & $\begin{array}{l}\text { Dynamic hedging (EC models) is bet- } \\
\text { ter than static hedging. }\end{array}$ \\
\hline $\begin{array}{l}\text { Chang et al., } \\
(2010)\end{array}$ & U.S. & $\begin{array}{l}\text { Crude oil and } \\
\text { Gasoline spot and } \\
\text { futures }\end{array}$ & $\begin{array}{l}\text { Jan. 1, } 1996 \\
\text { to Dec. } 31 \\
2005\end{array}$ & \begin{tabular}{|l|} 
OLS, MD- \\
GARCH, \\
BEKK-GARCH, \\
CCC-GARCH, \\
ECM-MD, \\
ECM- \\
BEKK,ECM- \\
CCC, State \\
space models \\
\end{tabular} & $\begin{array}{l}\text { Hedging effectiveness is higher in } \\
\text { bull markets than in bear markets }\end{array}$ \\
\hline Pradhan (2011) & India & $\begin{array}{l}\text { Nifty index and } \\
\text { Nifty index futures }\end{array}$ & $-\mathrm{NA}-$ & $\begin{array}{l}\text { OLS, VAR, } \\
\text { VECM, } \\
\text { M-GARCH }\end{array}$ & $\begin{array}{l}\text { Time-varying models (VEC-GARCH } \\
\text { and VAR-GARCH) reduced portfolio } \\
\text { variance to maximum extent }\end{array}$ \\
\hline $\begin{array}{l}\text { Chen and Tsay } \\
\text { (2011) }\end{array}$ & U.S.A. and U.K. & $\begin{array}{l}\text { S\&P500 and } \\
\text { FTSE100 }\end{array}$ & $\begin{array}{l}\text { May } 9,1984 \\
\text { to Aug. } 1, \\
2007 \text { and } \\
\text { Aug. } 82007 \\
\text { to July } 29 \\
2008 \\
\end{array}$ & $\begin{array}{l}\text { OLS, GARCH, } \\
\text { MRS-ARMA, } \\
\text { MRS-MA }\end{array}$ & $\begin{array}{l}\text { MRS-ARMA is superior over other } \\
\text { models. }\end{array}$ \\
\hline $\begin{array}{l}\text { Juhl et al., } \\
\text { (2012) }\end{array}$ & U.S.A & $\begin{array}{l}\text { Gasoline cash and } \\
\text { futures }\end{array}$ & $\begin{array}{l}\text { Jan. } 2006 \text { to } \\
\text { April } 2008\end{array}$ & OLS and ECM & $\begin{array}{l}\text { Longer hedge horizon yield optimal } \\
\text { hedge ratio close to } 1 \text { when cash } \\
\text { and future prices are cointegrated }\end{array}$ \\
\hline $\begin{array}{l}\text { Brooks et al, } \\
(2012)\end{array}$ & U.S. & \begin{tabular}{|l|} 
Corn, cotton, gold, \\
heating oil, silver, \\
soybean oil and \\
sugar future and \\
spot markets
\end{tabular} & $\begin{array}{l}\text { Jan. } 31,1979 \\
\text { to Sep. 30, } \\
2004\end{array}$ & OLS, MINIMAX & $\begin{array}{l}\text { Higher moments impact the op- } \\
\text { timal hedge ratios when returns } \\
\text { from hedged portfolio depart from } \\
\text { normality. }\end{array}$ \\
\hline
\end{tabular}

Source: Updated Table 1 in (Gupta \& Singh, Estimating the Optimal Hedge Ratio in Indian Equity Futures Market, 2009) 
Table 3: Descriptive Statistics

\begin{tabular}{|c|c|c|c|c|c|c|c|c|}
\hline Symbol & Variables & Period & Count & Mean & Std. Dev. & Skewness & Kurtosis & Jarque-Bera \\
\hline \multirow{6}{*}{$\begin{array}{l}\text { S\&PCNXNIFTY } \\
\text { (Near Month) }\end{array}$} & \multirow{2}{*}{$\begin{array}{l}\text { Futures } \\
\text { Return }\end{array}$} & Pre-Crisis & 1897 & 0.0008 & 0.02 & -1.01 & 12.43 & $7344.65(0.00)$ \\
\hline & & Post-Crisis & 1572 & 0.0001 & 0.02 & 0.04 & 12.30 & $5669.80(0.00)$ \\
\hline & \multirow{2}{*}{$\begin{array}{l}\text { Cash } \\
\text { Return }\end{array}$} & Pre-Crisis & 1897 & 0.0008 & 0.01 & -0.78 & 8.74 & $2795.45(0.00)$ \\
\hline & & Post-Crisis & 1572 & 0.0001 & 0.02 & 0.14 & 13.20 & $6823.50(0.00)$ \\
\hline & \multirow{2}{*}{ Basis } & Pre-Crisis & 1898 & -3.02 & 10.73 & -1.16 & 7.16 & $1793.99(0.00)$ \\
\hline & & Post-Crisis & 1573 & 8.60 & 15.92 & -0.08 & 4.75 & $201.74(0.00)$ \\
\hline \multirow{6}{*}{$\begin{array}{l}\text { S\&PCNXNIFTY } \\
\text { (Next Month) }\end{array}$} & \multirow{2}{*}{$\begin{array}{l}\text { Futures } \\
\text { Return }\end{array}$} & Pre-Crisis & 1897 & 0.0008 & 0.02 & -1.05 & 13.58 & $9194.46(0.00)$ \\
\hline & & Post-Crisis & 1572 & 0.0001 & 0.02 & -0.06 & 12.13 & $5465.49(0.00)$ \\
\hline & \multirow{2}{*}{$\begin{array}{l}\text { Cash } \\
\text { Return }\end{array}$} & Pre-Crisis & 1897 & 0.0008 & 0.01 & -0.78 & 8.74 & $2795.45(0.00)$ \\
\hline & & Post-Crisis & 1572 & 0.0001 & 0.02 & 0.14 & 13.20 & $6823.50(0.00)$ \\
\hline & \multirow{2}{*}{ Basis } & Pre-Crisis & 1898 & -5.78 & 16.2 & -1.17 & 5.44 & $908.54(0.00)$ \\
\hline & & Post-Crisis & 1573 & 25.21 & 29.36 & -0.04 & 3.20 & $2.99(0.22)$ \\
\hline \multirow{6}{*}{$\begin{array}{l}\text { S\&PCNXNIFTY } \\
\text { (Far Month) }\end{array}$} & \multirow{2}{*}{$\begin{array}{l}\text { Futures } \\
\text { Return }\end{array}$} & Pre-Crisis & 1897 & 0.0008 & 0.02 & -1.23 & 13.82 & $9740.50(0.00)$ \\
\hline & & Post-Crisis & 1572 & 0.0001 & 0.02 & -0.01 & 12.09 & $5407.43(0.00)$ \\
\hline & \multirow{2}{*}{$\begin{array}{l}\text { Cash } \\
\text { Return }\end{array}$} & Pre-Crisis & 1897 & 0.0008 & 0.01 & -0.78 & 8.74 & $2795.45(0.00)$ \\
\hline & & Post-Crisis & 1572 & 0.0001 & 0.02 & 0.14 & 13.20 & $6823.50(0.00)$ \\
\hline & \multirow{2}{*}{ Basis } & Pre-Crisis & 1898 & -6.66 & 21.53 & -0.71 & 5.04 & $489.67(0.00)$ \\
\hline & & Post-Crisis & 1573 & 39.75 & 41.16 & 0.03 & 2.67 & $7.48(0.024)$ \\
\hline \multirow{6}{*}{$\begin{array}{l}\text { CNXIT } \\
\text { (Near Month) }\end{array}$} & \multirow{2}{*}{$\begin{array}{l}\text { Future } \\
\text { Return }\end{array}$} & Pre-Crisis & 1091 & -0.0010 & 0.07 & -29.98 & 958.70 & $41683009(0.00)$ \\
\hline & & Post-Crisis & 1610 & 0.0005 & 0.02 & -1.12 & 15.85 & $11421.08(0.00)$ \\
\hline & \multirow{2}{*}{\begin{tabular}{|l|} 
Cash \\
Return
\end{tabular}} & Pre-Crisis & 1091 & -0.0010 & 0.07 & -30.13 & 965.59 & $42285710(0.00)$ \\
\hline & & Post-Crisis & 1610 & 0.0005 & 0.02 & -0.998 & 15.48 & $10709.18(0.00)$ \\
\hline & \multirow{2}{*}{ Basis } & Pre-Crisis & 1092 & 6.30 & 62.33 & -0.11 & 33.20 & $41513.72(0.00)$ \\
\hline & & Post-Crisis & 1611 & 6.53 & 20.74 & -0.50 & 8.51 & $2103.39(0.00)$ \\
\hline \multirow{6}{*}{$\begin{array}{l}\text { CNXIT } \\
\text { (Next Month) }\end{array}$} & \multirow{2}{*}{$\begin{array}{l}\text { Future } \\
\text { Return }\end{array}$} & Pre-Crisis & 1091 & -0.0011 & 0.13 & -6.01 & 334.08 & $4989438(0.00)$ \\
\hline & & Post-Crisis & 1610 & 0.0005 & 0.03 & -0.03 & 31.21 & $53368.76(0.00)$ \\
\hline & \multirow{2}{*}{$\begin{array}{l}\text { Cash } \\
\text { Return }\end{array}$} & Pre-Crisis & 1091 & -0.0010 & 0.07 & -30.13 & 965.59 & $42285710(0.00)$ \\
\hline & & Post-Crisis & 1610 & 0.0005 & 0.02 & -0.998 & 15.48 & $10709.18(0.00)$ \\
\hline & \multirow{2}{*}{ Basis } & Pre-Crisis & 1092 & 30.51 & 658.63 & 23.33 & 690.03 & $21575285(0.00)$ \\
\hline & & Post-Crisis & 1611 & -10.68 & 216.9 & -1.37 & 10.02 & $3818.326(0.00)$ \\
\hline \multirow{6}{*}{$\begin{array}{l}\text { CNXIT } \\
\text { (Far Month) }\end{array}$} & \multirow{2}{*}{$\begin{array}{l}\text { Future } \\
\text { Return }\end{array}$} & Pre-Crisis & 1091 & -0.0010 & 0.07 & -30.22 & 969.40 & $42620824(0.00)$ \\
\hline & & Post-Crisis & 1610 & 0.0004 & 0.02 & -2.28 & 64.93 & $258683.8(0.00)$ \\
\hline & \multirow{2}{*}{$\begin{array}{l}\text { Cash } \\
\text { Return }\end{array}$} & Pre-Crisis & 1091 & -0.0010 & 0.07 & -30.13 & 965.59 & $42285710(0.00)$ \\
\hline & & Post-Crisis & 1610 & 0.0005 & 0.02 & -0.998 & 15.48 & $10709.18(0.00)$ \\
\hline & \multirow{2}{*}{ Basis } & Pre-Crisis & 1092 & 348.84 & 2653.76 & 6.87 & 49.70 & $107821.6(0.00)$ \\
\hline & & Post-Crisis & 1611 & 51.38 & 286.45 & 0.28 & 4.56 & $184.10(0.00)$ \\
\hline
\end{tabular}




\begin{tabular}{|c|c|c|c|c|c|c|c|c|}
\hline \multirow{6}{*}{$\begin{array}{l}\text { BANKNIFTY } \\
\text { (Near Month) }\end{array}$} & \multirow{2}{*}{$\begin{array}{l}\text { Future } \\
\text { Return }\end{array}$} & Pre-Crisis & 637 & 0.0015 & 0.02 & -0.34 & 4.56 & $77.07(0.00)$ \\
\hline & & Post-Crisis & 1611 & 0.0003 & 0.02 & 0.17 & 7.92 & $1629.82(0.00)$ \\
\hline & \multirow{2}{*}{$\begin{array}{l}\text { Cash } \\
\text { Return }\end{array}$} & Pre-Crisis & 637 & 0.0016 & 0.02 & -0.25 & 4.48 & $65.10(0.00)$ \\
\hline & & Post-Crisis & 1611 & 0.0003 & 0.02 & 0.19 & 7.79 & $1549.99(0.00)$ \\
\hline & \multirow{2}{*}{ Basis } & Pre-Crisis & 638 & 6.64 & 23.44 & 0.16 & 6.01 & $242.80(0.00)$ \\
\hline & & Post-Crisis & 1612 & 13.70 & 36.38 & 0.15 & 3.83 & $52.57(0.00)$ \\
\hline \multirow{6}{*}{$\begin{array}{l}\text { BANKNIFTY } \\
\text { (Next Month) }\end{array}$} & \multirow{2}{*}{\begin{tabular}{|l} 
Future \\
Return
\end{tabular}} & Pre-Crisis & 637 & 0.0015 & 0.03 & -0.49 & 15.70 & $4307.52(0.00)$ \\
\hline & & Post-Crisis & 1611 & 0.0003 & 0.02 & 0.18 & 7.48 & $1352.79(0.00)$ \\
\hline & \multirow{2}{*}{$\begin{array}{l}\text { Cash } \\
\text { Return }\end{array}$} & Pre-Crisis & 637 & 0.0016 & 0.02 & -0.25 & 4.48 & $65.10(0.00)$ \\
\hline & & Post-Crisis & 1611 & 0.0003 & 0.02 & 0.19 & 7.79 & $1549.99(0.00)$ \\
\hline & \multirow{2}{*}{ Basis } & Pre-Crisis & 638 & 23.70 & 150.25 & 0.53 & 13.22 & $2806.04(0.00)$ \\
\hline & & Post-Crisis & 1612 & 36.04 & 65.31 & -0.02 & 5.04 & $278.75(0.00)$ \\
\hline \multirow{6}{*}{$\begin{array}{l}\text { BANKNIFTY } \\
\text { (Far Month) }\end{array}$} & \multirow{2}{*}{$\begin{array}{l}\text { Future } \\
\text { Return }\end{array}$} & Pre-Crisis & 637 & 0.0016 & 0.02 & 1.78 & 28.67 & $17823.39(0.00)$ \\
\hline & & Post-Crisis & 1611 & 0.0003 & 0.03 & -1.34 & 36.83 & $77316.5(0.00)$ \\
\hline & \multirow{2}{*}{\begin{tabular}{|l} 
Cash \\
Return
\end{tabular}} & Pre-Crisis & 637 & 0.0016 & 0.02 & -0.25 & 4.48 & $65.10(0.00)$ \\
\hline & & Post-Crisis & 1611 & 0.0003 & 0.02 & 0.19 & 7.79 & $1549.99(0.00)$ \\
\hline & \multirow{2}{*}{ Basis } & Pre-Crisis & 638 & 31.11 & 295.31 & 0.36 & 3.24 & $15.67(0.0004)$ \\
\hline & & Post-Crisis & 1612 & 66.75 & 238.99 & 2.07 & 26.81 & $39247.8(0.00)$ \\
\hline
\end{tabular}

Figures in parentheses represents $p$ value of JarqueBera Test statistics.

Table 4: Estimation of Optimal Hedge Ratio

\begin{tabular}{|c|c|c|c|c|c|c|c|c|c|}
\hline Symbol & Period & Naïve & OLS & ARMA OLS & $\begin{array}{c}\text { GARCH } \\
(1,1)\end{array}$ & $\begin{array}{c}\text { EGARCH } \\
(1,1) \\
\end{array}$ & $\begin{array}{c}\text { TGARCH } \\
(1,1) \\
\end{array}$ & VAR & VECM \\
\hline \multirow{2}{*}{$\begin{array}{l}\text { S\&PCNXNIFTY } \\
\text { (Near Month) }\end{array}$} & Pre-Crisis & 1 & 0.92 & 0.94 & 0.94 & 0.93 & 0.94 & 0.92 & 0.93 \\
\hline & Post-Crisis & 1 & 0.95 & 0.96 & 0.97 & 0.97 & 0.97 & 0.95 & 0.95 \\
\hline \multirow{2}{*}{$\begin{array}{l}\text { S\&PCNXNIFTY } \\
\text { (Next Month) }\end{array}$} & Pre-Crisis & 1 & 0.92 & 0.95 & 0.95 & 0.94 & 0.95 & 0.93 & 0.93 \\
\hline & Post-Crisis & 1 & 0.95 & 0.96 & 0.97 & 0.97 & 0.97 & 0.95 & 0.95 \\
\hline \multirow{2}{*}{$\begin{array}{l}\text { S\&PCNXNIFTY } \\
\text { (Far Month) }\end{array}$} & Pre-Crisis & 1 & 0.86 & 0.90 & 0.94 & 0.93 & 0.93 & 0.89 & 0.89 \\
\hline & Post-Crisis & 1 & 0.96 & 0.96 & 0.97 & 0.97 & 0.97 & 0.95 & 0.96 \\
\hline \multirow{2}{*}{$\begin{array}{l}\text { CNXIT } \\
\text { (Near Month) }\end{array}$} & Pre-Crisis & 1 & 0.990 & 0.999 & 0.999 & 0.998 & 0.996 & 0.997 & 0.998 \\
\hline & Post-Crisis & 1 & 0.98 & 0.99 & 1.004 & 1.005 & 1.003 & 0.98 & 0.98 \\
\hline \multirow{2}{*}{$\begin{array}{l}\text { CNXIT } \\
\text { (Next Month) }\end{array}$} & Pre-Crisis & 1 & 0.33 & 0.38 & 0.36 & 0.30 & 0.31 & 0.87 & 0.88 \\
\hline & Post-Crisis & 1 & 0.21 & 0.22 & 0.36 & 0.36 & 0.36 & 0.22 & 0.22 \\
\hline \multirow{2}{*}{$\begin{array}{l}\text { CNXIT } \\
\text { (Far Month) }\end{array}$} & Pre-Crisis & 1 & -0.018 & -0.018 & -0.01 & -0.02 & -0.001 & -0.10 & -0.10 \\
\hline & Post-Crisis & 1 & 0.13 & 0.13 & 0.09 & 0.09 & 0.09 & 0.13 & 0.14 \\
\hline \multirow{2}{*}{$\begin{array}{l}\text { BANKNIFTY } \\
\text { (Near Month) }\end{array}$} & Pre-Crisis & 1 & 0.95 & 0.98 & 0.98 & 0.99 & 0.99 & 0.96 & 0.96 \\
\hline & Post-Crisis & 1 & 0.97 & 0.98 & 0.98 & 0.98 & 0.99 & 0.97 & 0.97 \\
\hline \multirow{2}{*}{$\begin{array}{l}\text { BANKNIFTY } \\
\text { (Next Month) }\end{array}$} & Pre-Crisis & 1 & 0.38 & 0.37 & 0.38 & 0.38 & 0.38 & 0.38 & 0.42 \\
\hline & Post-Crisis & 1 & 0.95 & 0.98 & 0.99 & 0.99 & 0.99 & 0.97 & 0.97 \\
\hline \multirow{2}{*}{$\begin{array}{l}\text { BANKNIFTY } \\
\text { (Far Month) }\end{array}$} & Pre-Crisis & 1 & 0.019 & 0.008 & 0.001 & -0.003 & -0.008 & 0.012 & 0.062 \\
\hline & Post-Crisis & 1 & 0.43 & 0.44 & 0.99 & 0.99 & 0.99 & 0.53 & 0.54 \\
\hline
\end{tabular}


Table 5: Portfolio Variance Reduction (Percentage)

\begin{tabular}{|c|c|c|c|c|c|c|c|c|c|}
\hline Symbol & Period & Naive & OLS & $\begin{array}{l}\text { ARMA } \\
\text { OLS }\end{array}$ & $\begin{array}{c}\text { GARCH } \\
(1,1)\end{array}$ & $\begin{array}{c}\text { EGARCH } \\
(1,1)\end{array}$ & $\begin{array}{c}\text { TARCH } \\
(1,1)\end{array}$ & VAR & VECM \\
\hline \multirow{2}{*}{$\begin{array}{l}\text { S\&PCNXNIFTY } \\
\text { (Near Month) }\end{array}$} & Pre-Crisis & 93.81 & 94.55 & 94.47 & 94.5 & 94.53 & 94.51 & 94.54 & 94.54 \\
\hline & Post-Crisis & 98.07 & 98.37 & 98.35 & 98.33 & 98.31 & 98.31 & 98.37 & 98.37 \\
\hline \multirow{2}{*}{$\begin{array}{l}\text { S\&PCNXNIFTY } \\
\text { (Next Month) }\end{array}$} & Pre-Crisis & 92.80 & 93.49 & 93.40 & 93.41 & 93.43 & 93.41 & 93.48 & 93.47 \\
\hline & Post-Crisis & 97.92 & 98.21 & 98.19 & 98.17 & 98.17 & 98.16 & 98.20 & 98.20 \\
\hline \multirow{2}{*}{$\begin{array}{l}\text { S\&PCNXNIFTY } \\
\text { (Far Month) }\end{array}$} & Pre-Crisis & 82.64 & 84.99 & 84.75 & 84.29 & 84.31 & 84.31 & 84.90 & 84.89 \\
\hline & Post-Crisis & 97.96 & 98.18 & 98.17 & 98.15 & 98.15 & 98.15 & 98.18 & 98.18 \\
\hline \multirow{2}{*}{$\begin{array}{l}\text { CNXIT } \\
\text { (Near Month) }\end{array}$} & Pre-Crisis & 99.55 & 99.56 & 99.55 & 99.55 & 99.56 & 99.56 & 99.56 & 99.56 \\
\hline & Post-Crisis & 96.63 & 96.69 & 96.68 & 96.63 & 96.63 & 96.63 & 96.68 & 96.68 \\
\hline \multirow{2}{*}{$\begin{array}{l}\text { CNXIT } \\
\text { (Next Month) }\end{array}$} & Pre-Crisis & -97.51 & 32.19 & 31.48 & 31.98 & 31.95 & 32.01 & -53.48 & -55.07 \\
\hline & Post-Crisis & -146.9 & 10.74 & 10.70 & 05.01 & 05.09 & 04.9 & 10.70 & 10.66 \\
\hline \multirow{2}{*}{$\begin{array}{l}\text { CNXIT } \\
\text { (Far Month) }\end{array}$} & Pre-Crisis & -100.1 & 00.03 & 00.03 & 00.026 & 00.03 & 00.026 & -00.68 & -00.63 \\
\hline & Post-Crisis & -95.61 & 02.18 & 02.18 & 01.97 & 01.97 & 01.97 & 02.18 & 02.17 \\
\hline \multirow{2}{*}{$\begin{array}{l}\text { BANKNIFTY } \\
\text { (Near Month) }\end{array}$} & Pre-Crisis & 95.96 & 96.22 & 96.15 & 96.12 & 96.09 & 96.12 & 96.21 & 96.20 \\
\hline & Post-Crisis & 98.55 & 98.65 & 98.63 & 98.63 & 98.63 & 98.62 & 98.65 & 98.65 \\
\hline \multirow{2}{*}{$\begin{array}{l}\text { BANKNIFTY } \\
\text { (Next Month) }\end{array}$} & Pre-Crisis & -58.94 & 33.97 & 33.96 & 33.97 & 33.96 & 33.97 & 33.97 & 33.44 \\
\hline & Post-Crisis & 95.99 & 96.32 & 96.2 & 96.13 & 96.10 & 96.10 & 96.27 & 96.25 \\
\hline \multirow{2}{*}{$\begin{array}{l}\text { BANKNIFTY } \\
\text { (Far Month) }\end{array}$} & Pre-Crisis & -153.7 & 00.06 & 00.04 & 00.008 & -00.02 & -00.06 & 00.05 & -00.24 \\
\hline & Post-Crisis & -21.2 & 27.4 & 27.37 & -18.84 & -19.18 & -19.18 & 25.99 & 25.59 \\
\hline
\end{tabular}

Table 6: Descriptive Statistics of Futures Contracts Volume

\begin{tabular}{|c|c|c|c|c|c|c|c|}
\hline Symbol & $\begin{array}{c}\text { Contract } \\
\text { month }\end{array}$ & Period & Count & Mean & Minimum & Maximum & Std. Dev. \\
\hline \multirow{6}{*}{ S\&PCNXNIFTY } & \multirow{2}{*}{ Near } & Pre & 1898 & 135556.2 & 19 & 1338598 & 183077.1 \\
\hline & & Post & 1573 & 427064.2 & 14371 & 1251159 & 208680.7 \\
\hline & \multirow{2}{*}{ Next } & Pre & 1898 & 17196.69 & 0 & 456357 & 47617.18 \\
\hline & & Post & 1573 & 58028.91 & 331 & 654667 & 92553.04 \\
\hline & \multirow{2}{*}{ Far } & Pre & 1898 & 351.8298 & 0 & 11833 & 799.4081 \\
\hline & & Post & 1573 & 2416.155 & 11 & 25076 & 2501.269 \\
\hline \multirow{6}{*}{ CNXIT } & \multirow{2}{*}{ Near } & Pre & 1092 & 471.1612 & 0 & 3683 & 480.5841 \\
\hline & & Post & 1611 & 264.2384 & 1 & 3028 & 243.8575 \\
\hline & \multirow{2}{*}{ Next } & Pre & 1092 & 50.45238 & 0 & 3164 & 213.6881 \\
\hline & & Post & 1611 & 34.89758 & 0 & 2981 & 121.7317 \\
\hline & \multirow{2}{*}{ Far } & Pre & 1092 & 0.130952 & 0 & 50 & 1.882008 \\
\hline & & Post & 1611 & 0.109870 & 0 & 20 & 0.860288 \\
\hline \multirow{6}{*}{ BANKNIFTY } & \multirow{2}{*}{ Near } & Pre & 638 & 2011.188 & 27 & 10453 & 1.409485 \\
\hline & & Post & 1612 & 60314.10 & 557 & 343417 & 38311.60 \\
\hline & \multirow{2}{*}{ Next } & Pre & 638 & 173.9169 & 0 & 3087 & 432.0245 \\
\hline & & Post & 1612 & 6517.636 & 0 & 92572 & 12209.66 \\
\hline & \multirow{2}{*}{ Far } & Pre & 638 & 0.147335 & 0 & 32 & 1.382868 \\
\hline & & Post & 1612 & 139.6712 & 0 & 3801 & 259.1689 \\
\hline
\end{tabular}


Table 7: Correlation Coefficient of Return Series

\begin{tabular}{|c|c|c|c|c|}
\hline Symbol & Contract month & Period & Count & Correlation Coefficient \\
\hline \multirow{6}{*}{ S\&PCNXNIFTY } & \multirow{2}{*}{ Near } & Pre & 1897 & 0.973 \\
\hline & & Post & 1572 & 0.992 \\
\hline & \multirow{2}{*}{ Next } & Pre & 1897 & 0.967 \\
\hline & & Post & 1572 & 0.992 \\
\hline & \multirow{2}{*}{ Far } & Pre & 1897 & 0.922 \\
\hline & & Post & 1572 & 0.991 \\
\hline \multirow{6}{*}{ CNXIT } & \multirow{2}{*}{ Near } & pre & 1091 & 0.999 \\
\hline & & Post & 1610 & 0.984 \\
\hline & \multirow{2}{*}{ Next } & Pre & 1091 & 0.568 \\
\hline & & Post & 1610 & 0.328 \\
\hline & \multirow{2}{*}{ Far } & Pre & 1091 & -0.0180 \\
\hline & & Post & 1610 & 0.148 \\
\hline \multirow{6}{*}{ BANKNIFTY } & \multirow{2}{*}{ Near } & Pre & 637 & 0.982 \\
\hline & & Post & 1611 & 0.994 \\
\hline & \multirow{2}{*}{ Next } & Pre & 637 & 0.584 \\
\hline & & Post & 1611 & 0.982 \\
\hline & \multirow{2}{*}{ Far } & Pre & 637 & 0.024 \\
\hline & & Post & 1611 & 0.524 \\
\hline
\end{tabular}

